University of Michigan Law School

University of Michigan Law School Scholarship Repository

Articles

Faculty Scholarship

1904

\title{
A Proposed National Incorporation Law
}

Horace LaFayette Wilgus

University of Michigan Law School

Available at: https://repository.law.umich.edu/articles/19

Follow this and additional works at: https://repository.law.umich.edu/articles

Part of the Business Organizations Law Commons, Constitutional Law Commons, and the Legislation Commons

\section{Recommended Citation}

Wilgus, Horace LaFayette. "A Proposed National Incorporation Law." Mich. L. Rev. 2 (1904): 501-594.

This Article is brought to you for free and open access by the Faculty Scholarship at University of Michigan Law School Scholarship Repository. It has been accepted for inclusion in Articles by an authorized administrator of University of Michigan Law School Scholarship Repository. For more information, please contact mlaw.repository@umich.edu. 


\section{MICHIGAN \\ LAW REVIEW}

VoI. II

APRIL, 1904

No. 7

\section{- A PROPOSED NATIONAI, INCORPORATION IAW}

$T N$ an article in the February number of this magazine ${ }^{I}$ the writer 1 discussed the need of a national incorporation law. The following is proposed as such; its object is to set forth what, perhaps, may be possible under'such a law; what some will thinl necessary or desirable; what some will think unnecessary and undesirable; and what others will undoubtedly think is all wrong, if not vicious. Whatever view is taken the writer's purpose will be accomplished if consideration and discussion of the proper details of such a law, are provoked. /There are two classes who desire a national incorporation law those who believe such is necessary for the proper regulation of the large corporations engaged in national commerce, in order to promote the general welfares gland those engaged in such commerce who wish to be relieved from the inconvenience and unequal or unjust burdens arising from conflicting state regulations the former will be inclined to favor a law something similar to this, and the latter only such a national law as would give all the rights and powers the most liberal state law nowgives, and relieves from all the restraints that more rigid state laws impose. As between these two the former have been in mind latter. There are probably also two classes opposed to a national law, - those who believe such a law would shift the balance of powers from the states to the national government, and be disastrous; and those who find opportunity for floating fraudulent schemes, or securing powers and privileges that enable them to enrich themselves at the expense of others, without danger of punishment,-reap all the benefits and escape all the burdens. As between these two, the latter have been in mind rather than the former.

It is not the duty of the government to act as a parent of its people; neither is it the duty of the government to clothe a part of its people with great powers and privileges, peculiarly susceptible of

12 ITrCHIOAN I,AW REVIEW, D. 358. 
abuse, without providing reasonable protection against, and adequate remedy for, such abuse. The writer believes that the corporation is the most efficient business machine jet invented; and its very efficiency makes it, in the hands of the honorable, most beneficent; but in the hands of those otherwise disposed, most oppressive. The vast majority of business men are honorable, and need but little, if any, restraint beyond their own consciences; there are, however, many others who are bent upon securing and exercising undue advantage over their fellows; the former, not needing restraint, will not, or should not, feel hampered by such restraints as are made necessary by the latter; while the law cannot make men better, it may make it more difficult for them to injure their neighbor, -and this is the standpoint from which many provisions herein should be judged. Many of the provisions are designed to meet the evils that the investigations of the Industrial Commission, the Interstate Commerce Commission, and the Commissioner of Iabor have found to exist,-over-capitalization, unjust discriminations, predatory competition, oppressive'combinations, unjust, unsafe, and unsanitary conditions of labor, and insufficient publicity either for safe investment or proper legislation. Nearly every section has been prepared only after a careful and long-con'tinued-consideration of the provisions of the Einglish Companies' Acts, the national banking law, the new Massachusetts law, the law proposed (but not adopted) for New York in 1900, the New Jersey law, and the new Virginia law of last pear. These have been worked over in order to make a consistent whole and such additions and modifications made as seemed necessary to meet the conditions believed to exist. Inasmuch as there is no common law of the United States, ${ }^{1}$ it seems necessary that a national corporation law should be in the nature of a code of corporation law, and calls for many provisions which would not otherwise be required.

So far as the writer is aware, with the exceptions of the single section proposed by Mr. Stimson to the Industrial Commission, ${ }^{2}$

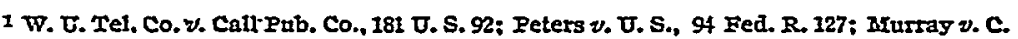
\& N. W. R. Co., 62 Fed. R. 24.

s "Any state corporation engaged in interstate commerce, or ang number of citizens of the United States desirous of forming a corporation for the purpose of engaging in interstate commerce either by the transportation of persons or property, or by other traffic or commerce among the states, may be organized as a Federal Corporation under this act, and as such may sue or be impleaded in the Federal courts, and such Corporation shall not be sabject to taxation under the laws of any state except as to property actually situated within such state." -19 Indus. Com. Report, D. 695. 
the five points proposed by Mr. W. S. Iogan, and the eight requirements insisted on by Mr. James $B$. Dill, ${ }^{2}$ only one other draft of a national incorporation law has been published, 一that of Hon. H. W. Palmer, of Pennsylvania, introduced by him in the House of Representatives, November 9, 1903, (58th Congress H. R. 66). Most of the following provisions had been worked out before a copy of that bill was seen by the writer. It has (with some proposed amendments) been approved by the National Board of Trade, and referred to the Judiciary Committee. It is commendable for its brevity; it follows Mr. Stimson's advice not to undertake to define interstate commerce, nor to compel incorporation under it; it leaves most of the legal problems to be worked out by the courts of a government having no common law; it makes excellent provisions for securing the payment of stock, but does not otherwise seem to be designed to meet any of the other difficulties pointed out by the public commissions that have.so long considered these matters; it is as liberal in permitting the promoters to mould, and the directors to manage, the corporate body to suit themselves, without any liability or report, as the most liberal corporation law of any state; it contains the objectionable (but popular with corporation promoters) feature of the New. Jersey law allowing the incorporators to create and confer upon themselves any corporate power they choose "not contrary to this Act, and the Constitution

1 arr. Logan's propositions suggested: (1) That a bureau of incorporations be established under the control of the Attorney-General; (2) That corporations be allowed to form under articles of incorporation stating the things usually required; (3) "That no corporation shall engage in commerce between any one state and ans other state unless it shall be incorporated under this act or shall have accepted the vrovisions of it." (4) Corporations tending . to create monopolies should not be allowed to engage in interstate commerce; and (5) The J:S. Circuit Courts have juris dirtion to enjoin violátions or entertain suits for damages.- $-37^{\circ}$ Am. I.art Revier,-March-Apr. 1903, D. 237, 247.

2 Ar. Dill's propositions may be summarized as follows: (1) Optional to organize under such act; (2) The name "National" should be forbidaen to anp corporation not organized under such Iar: (3) Protection from state attachment Iaws, etc; (4) Assurance of privileges and immunities guaranteed to riatural persons by the constitution, and discriminatiön by state laws forbidden; (5) Freedom from state supervision, subject to state taration onjy on property in the state, as an individual. (6) National supervision, examination, and private pubticity; (7) Annual report to Federal authorities showing taring silus, collated by Federal authority and furnished to state officers to insure just taration; (8) Taxation on property Iocalls where situnted. Stock in hands of stockhoiders exempt from taration,-Adaress, Farvard Univ.. Blarch 10, 1902, D. 27-8. 
of the United States," "I-a provision broad enough if the words are given their ustual meaning to enable such a corporation wholly to ignore any state laws, and with the power conferred to acquire and vote the stock of any other corporation whatever, (Sec. 26), to form any combination that the Anti-trust act was designed to prevent; no reference is made to the Interstate Commerce law, the Department of Commerce and Iabor law, nor the Anti-trust act, indicating whether they would apply or not. In shott the purpose of the act is apparently to induce incorporation under it, by making it nearly as liberal as the New Jersey law, and yet supported by the national arm. The writer does not believe in the national government bidding this high to encourage and perpetuate, clothed with national. power, the precise kind and quality of institution that already afflicts us. Many of the provisions of the following proposed act perhaps will not meet with general approval: as the prohibition on certain corporations not formed under this act to engage in national commerce; the deliberation required in forming a corporation,association, ${ }^{2}$ organization meeting, ${ }^{3}$ articles of organization, ${ }^{4}$ certificate of incorporation, ${ }^{5}$ certificate to commence business ${ }^{6}$ the prospectus $;^{7}$ issue and payment of stock $^{8}$ increasing incorporation ${ }^{9}$ and franchise ${ }^{10}$ fees as the capital stock and franchise increase; power to engage in manufacturing, etc. $i^{11}$ forbidaing the acquisition of shares in other corporations, ${ }^{12}$ or allowing its shares to be so acquired; ${ }^{13}$ consolidation; ${ }^{14}$ application of the interstate Commerce, ${ }^{15}$ Department of Commerce, ${ }^{18}$ and the Anti-trust ${ }^{17}$ laws; rebates; $;^{18}$ predatory competition; $;^{19}$ employers' liability; $;^{20}$ compulsory arbitration, under certain conditions; ${ }^{21}$ safety of laborers; ${ }^{22}$ purchase by the government; ${ }^{23}$ annual reports, etc. ${ }^{24}$ It is not designed to make an argument in favor of any of these; but as to the first, (prohibiting

1 The provision reads: "Sec. 4. That certificate of incorporation may also contain any provisions which the incorporators may choose to insert for the regulation of the business and for the conduct of the corporation, and any frovisions creating, defining, limiling, and regutating thepowersof the corporation. the directors and the stockinolder, or any classes of the stocikholders: Provided, That such provisions are not contrary to this Act or to the Constitution of the Dnited States."

\begin{tabular}{|c|c|c|c|}
\hline 1 Sections 7-16 & \& $32358-62$ & $38270-7.3$ & +374 \\
\hline 5 8ะ 76-79 & - $2381-83$ & $73364-69$ & $83242-47$ \\
\hline - 380 & $\left.{ }^{10} \not 2148(2)\right]$ & 11 路 59,85 & 13887 \\
\hline 13 दृ 87 & 14 玩 96-98 & 15 路 $87(5), 237$ & $16 \& 87(5)$ \\
\hline $37387(5)$ & $18,32 \quad 138-9$ & 13 ใُ己 140-141a & $=0 \geqq 146$ \\
\hline $31 \& 145$ & .22321424 & 23 ह 135 & 24 Z 247 \\
\hline
\end{tabular}


certain companies) the writer believes that so long as honorable men can and do conduct an honorable business in an honorable way under the New Jersey law, or a similar one; and the dishonorable can do, and do, otherwise, and as these make up all, there is very little likelihood that either will organize under a national law less liberal than the New Jersey law, unless some pressure is brought to bear; such was the experience with the national banking act; since this proposed law is not designed to outbid the "liberal" states for corporate patronage, but to remedy existing abuses, it undertakes to make provision for the necessary pressure to be applied, as was done in the national banking law, to accomplish the purpose. The writer, however, believes there is no provision that need or will obstruct or unduly hamper honorable and legitimate enterprise, but would rather strengthen, build up, restore confidence in, and induce investment in the same by the people generally, when the fungous growths are amputated or prevented. No one realizes more fully than the writer, the difficulty of putting in words suitable provisions adequately to meet existing conditions and tendencies, without overlooking much, or overdoing much. From the nature of the topic, and the extent of the interests involved, if forno other reason, almost any proposed law should receive full, fair, and just consideration, criticism and discussion. And in the multitude of counselors wisdom will be found.

An Act to Regulate National Commerce, to Prohibit Certain Companies from Engaging therein, and to Provide for the Formation and Regulation of Corporations to Engage therein.

$\S 1$. Be it Enacted by the Senate and House of Representatives of the United States of America in Congress assembled, as follows:-

This Act shall consist of thirteen parts as follows:-

I. Preliminary. II. Certain Companies forbidden to engage in National Commerce. III. Constitution of Corporations to engage in National Commerce. IV. Formation of such Corporations. V. Powers of such Corporations. VI. Management. of such Corporations. VII. Duties and liabilities of such Corporations. VIII. Control and supervision of such Corporations. IX. Rights and liabilities of members. $X$. Rights and liabilities of officers. $\mathrm{Xr}$. Rights of creditors. XII. Penalties. XIII. Dissolution and winding up. 


\section{PREITIMINARY.}

\$ 2. Short Title. This Act may be cited as the National Corporation Iaw.

§3. Commencement. This Act shall come into operation on the first day of January, 1907.

- § 4. Definitions. (1.) "National Commerce," shall consist of commerce with foreign nations and among the several states, and without excluding other things, shall include the transit or transportation of persons or things from any place in one state to any place within another state, by any method now or hereafter used or devised; the transmission of intelligence from any place or person; within any state to a place or person within any other state, by any method now or hereafter used or devised, except through the United States mails; the buying of any personal property or commodity of any kind whatever by any person in any state, from any person in the same or in any other state, or the selling of the same by the latter to the former, or the exchange of such property if the property or commodity bought, sold or exchanged, is to be delivered in, or transported or taken ints, any state other than the one in which it is located, owned, or used at the time of purchase, sale, or exchange.

(2.) "State" shall include the United States, or any state of the United States, or any of the territories, colonies, or possessions thereof, or any foreign country state, territory, colony, or possession, unless the context otherwise indicates.

(3.) "United States," unless the context otherwise indicates, shall include all the territory now or hereafter belonging to, or held by, or subject to the jurisdiction of the United States.

(4.) "Company" shall include any form of partnership, association, partnership association, joint-stock company, limited partnership, corporation, trust, combination, or any other form of association whatever, now or hereafter known, used, or devised, composed of seven or more persons, or having a capital stock of one million dollars or over, with transferable shares, or having or controlling that amount of property, engaged in, carrying on, or controlling national commerce or any part thereof, whether such company is a transportation company, a transmission company, or a trading company, except a state or public corporation.

(5.) "Transportation company" shall include any such company, or any trustee, receiver, or representative thereof, owning, 
controlling, leasing, managing, or operating for hire a railroad, . street railway, canal, steamboat, steamship, pipe. line, sleeping car, freight car, fast freight line, express, or any other instrument or vehicle now or hereafter used or devised, in any way engaged in the, business of a carrier of national commerce.

(6.) "Transmission company" shall include any such company, or any trustee, receiver or representative thereof, owning, controlling, leasing, managing, or operating for hire any telegraph, or telephone line, or other instrument or device now or hereafter used or devised for the purpose of transmitting intelligence from or to any person or place in one state to or from another person or place in another state, except through the United States mails.

(7.) "Trading company" shall include all such companies of whatever kind or any trustee, receiver, or representative thereof, engaged in buying or selling personal property or commodities of any kind, as a part of its regular business, and whether such products are produced by such company or not, if the same are bought or sold to be delivered, or transported, or taken, into any state other than the one in which they are located, owned or used at the time of purchase or sale.

(8.) "Carrying on," or "engaging in" national trade or commerce shall consist in doing these things'as a part of the regular business of any such company, whether the same is organized for that purpose or not.

(9.) "Controlling" national trade or commerce shall include any method now or hereafter used or devised whereby any positive influence is in fact exerted over such trade or commerce, or any part thereof, through the agency of any person or persons however accomplished and in whatsoever manner they may be associated together or organized."

(10.) "Person". unless the context otherwise indicates, shall include partnerships, associations, partnership associations, jointstock companies, limited partnerships, companies, corporations, or any other association of any kind whatever, composed of either natural or artificial persons, except a state or public corporation.

$\S 5$. Interpretation. It is hereby declared that the main purpose of this Act is to regulate national commerce by providing for the formation and control of corporations to engage therein; and this Act shall be interpreted liberally to accomplish that purpose in order to promote the publis welfare; if the sections hereinafter con- 
tained forbidding certain companies not formed under this Act from engaging in such commerce without complying with this Act; or if the sections and parts of sections permitting trading corporations formed under this Act to engage in other lines of business, and the sections or parts of sections regulating such business, so far as they . relate thereto; or if the definitions herein given of national commerce, should be held by the courts to be in any particular beyond the constitutional powers of Congress, then all such sections, or parts of sections, and provisions, so applied, are hereby declared not to be essential to the main purpose of this Act, but to be surplusage only, when so applied, and shall in no way invalidate or affect the interpretation and application of such provisions to such matters as are within the power of Congress, or of the other sections and provisions of this act so as to accomplish the main purpose hereof.

$\$$ 6. Common Law to Apply.. All questions arising under the provisions of this Act not expressly provided for, whether the same relate to matters of commerce, or matters of corporation law, or to other matters, shall be determined by the rules of the common law of the subject matter involved, as the same may be determined, and applied by the courts of the United States having occasion to consider such questions.

\section{CERTAIN COMTPANIES NOT TO ENGAGE IN NATIONAL COMMIERCE.}

\$ 7. Prohibition. No such. company as above defined heretofore or hereafter existing or operating, within the United States, for the purpose or with the power of engaging in, carrying on, or controlling, directly or indirectly, national commerce, shall engage in, or carry on, or control, directly or indirectly any such national commerce, unless such company shall reorganize under the provisions of section 12 of this act, or shall pay the tax fixed by section 8 hereof; and no such company shall hereafter use "National," or "United States," as a part of its name.

\$ 8. Tax Ímposed. Every such company which does not reorganize under and comply with the provisions of this Act on or before the first day of January, 1907, shall thereafter be subject to a tax of one per cent upon the total value of the national commerce carried on by such company for each month thereafter, for the privilege of engaging in such commerce. The value of such commerce, in the case of trading companies, shall be the total value of 
the national commercial products bought, sold or exchanged by it for each month; and in the case of transportation or transmission companies, the value of the national commerce shall be the gross receipts therefrom for each month.

\$ 9. Annual Statement. Every such company that fails to reorganize under section 12 of this Act shall file on or before August first in each year with the collector of internal revenue of the district wherein the principal office of such company is located, a statement setting forth, under the oath of the president or chief officer, or the members, thereof, upon blanks to be furnished by the Commissioner of Internal Revenue, with the approval of the Secretary of the Treasury, such items as may be prescribed by such Commissioner, and as shall fully, truly, and accurately exhibit the national commerce carried on monthly during the preceding year ending June 30th; such statements shall be forwarded to the Commissioner of Internal Revenue, who shall assess the fee thereon according to section 8 herein, and the same shall be due and shall be collected, and all the provisions of the United States statutes , concerning the collection of internal revenue, shall be held to apply, as provided in section 148 herein.

$\$ 10$. License to be Issued. If such tax is paid when due, a cerrificate thereof stating the date of payment, issued by the Commissioner of Internal Revenue, and countersigned by the collector of the district, in which the principal office is located, shall be delivered to such company, and shall be, and have the effect of, a license to engage in national commerce until July first of the year following that for which report is made.

$\S$ 11. May Reorganize under this Act. Every such company now or hereafter existing within the United States engaging in, carrying on, or controlling directly or indirectly, such national commerce, may, by complying. with the provisions (of section 12 of this Act) reorganize under it as a national corporation and therby obtain the rights, privileges and immunities, and be subject to all the duties and liabilities, thereof; and likewise the officers, shareholders, and agents of such reorganized corporation shall have all the rights and be subject to all the duties, liabilities, and penalties contained in this Act.

\$ 12. Method of Reorganizing. In case such company desires so to reorganize, the directors, if any, thereof shall first pass a resolution 
recommending reorganization under this Act, and shall call a meeting of members, for the purpose of considering the same, giving such notice thereof, and proceeding as is provided in section 94 herein, in regard to the making of material amendments to the charer of corporations after organization under this Act; if the proposition to reorganize shall be adopted at such meeting by a vote of not less than two-thirds of the shares outstanding, or of the members, the president, secretary, and the directors, if any, or the members thereof shall make and sign as provided in section 74 herein, Articles of Organization, which shall state the things required in organizing a corporation under this Act, and in addition thereto such articles shall contain, or be accompanied by, a copy of the special, or definite reference to the general, law, under which the company was originally organized, or the original agreement, if any, or certificate of incorporation if organized under a general law, and the by-laws, or other organization papers, if any; and shall further state that they have been authorized by the vote of the owners of two-thirds of the stock, or of the members, to make such certificate and to change said company into a national corporation under this Act; such Articles of Organization shall be submitted to the Commissioner of Corporations for approval, and if approved, shall, upon the payment of the fees provided in section 80 be filed in the office of the Secretary of the Department of Commerce and Iabor, who shall issue a certificate of incorporation under the same conditions, and with the same effect, and which shall be filed, recorded, and published, as provided in sections 75 to 78 herein, in regard to corporations formed under this Act. Such company may keep the same name, subject to the provisions of sections 36,37 , and continue the same directors intil new ones are elected and qualified.

§ IB. Penalty. Any such company, failing to reorganize under this Act or pay the tax or fee provided in section 8 , or using the name forbidden in section 7 , continuing to engage in national commerce contrary to the provisions of this act is hereby declared to be guilty of a crime against the United States, and such company shall be punished by a fine of not less than one thousand dollars, nor more than ten thousand dollars, and the natural persons comprising, managing, or directing such company so offending, with their knowledge and consent shall likewise be subject to the same penalty. Elach month's repetition thereof shall be a new offense. It is 
hereby made the duty of the grand juries in the various districts of the United States to investigate alleged violations of this Act by such parties and of the district attorneys to prosecute the same, as in other cases of crime against the United States.

\$ 14. Injunction. It is also hereby made the duty of the district attorneys in the various districts of the United States, under such Iules and regulations as may be prescribed by the Attorney-Gen-. eral of the United States to bring proceedings in the Circuit Courts of the district in which the principal office of such company is located,-jurisdiction to try such cases being hereby conferred upon said courts, to perpetually oust and enjoin every such company from carrying on, engaging in, or controlling such commerce, until the same has complied with this Act.

\$ 15. Contracts not Enforceable. All contracts relating to national commerce made by any such company not having first complied with this Act, shall be unenforceable by such company in any of the courts of the states or of the United States; but any person or company not engaged in such commerce, and not subject to the provisions of this Act, or if subject thereto has complied therewith, who or which, in good faith has entered into any contract with such offending company and has wholly or partly performed his part of such contract, may enforce the same against such offending company.

\$16. Officers Personally Liable. 'The directors, officers, agents, and members of any such company, not having complied with this Act, shall be jointly and severally personally liable upon any $\cdot$ contract made, or wrong done, by it to the other party if the latter is not subject'to, or has complied with, this Act, without any right of indemuity or contribution among themselves.

III. CONSTITOTION OF CORPORATIONS TO FNGAGE IN NATIONAI, COATIERCE.

\section{In General.}

§ 17. Anthority to Form. Corporations may be formed under the provisions of this Act for the purpose and with the power of engaging in, or carrying on national commerce.

\$ 18. Charter. Such corporation shall have a charter which shall consist of the provisions of this Act and the amendments thereto, and the Certificate of Incorporation hereinafter provided for.

$\$ 19$. Composition. Such corporation shall be composed of members, directors, and officers, and shall have a corporate name, a reg- 
istered office, a capital stock divided into shares, and shall enact $b y$ Laws for its regulation.

Such corporation shall be formed, shall have such powers, shall be managed, shall be subject to such duties and liabilities, shall be subject to such control and supervision, with such rights, duties, and liabilities of members, officers and creditors, shall be subject to such penalties, and shall be dissolved and wound up, as hereinafter provided.

\section{Members.}

$\S 20$. Necessity. Every such corporation shall have and contirue to have at least seven-members, each of whom shall own at least one share of stock. Failure to have such number of members shall have the effect indicated in sections $149,184,187$.

$\S 21$. Acquisition of Membership. Membership may be acquired in such corporation before incorporation by subscribing to the Agreement of Association, hereinafter mentioned, indicating the shares agreed to be taken; or by accepting or agreeing to accept any office for which qualification by ownership of shares is required, to the extent thereof; or by subscription to the capital stock; or by agreement to purchase or take shares, in such corporation. made by the mutual promises of the parties thereto; or by contract with the promoters or incorporators; or by underwriting contract; and accepted, adopted, or acted upon with full knowledge by such corporation; or, after incorporation, by contract of subscription or purchase made with its duly authorized agent; or by accepting any office for which qualification shares are required, to the extent thereof, so fat as the corporation has unissued shares; or by transfer of shares from a former owner, or his personal representative; or by operation of law.

\section{Directors.}

\$22. Number. Such corporation shall have not less than five directors, but may have as many more as are provided for in the Agreement of Association.

$\$ 23$. Qualifications. (1.) Residence: At least one-third of the whole number of directors shall during office, continuously reside within the United States.

(2.) Ownership of shares. The ownership of at least five shares, or such other greater number as may be required by the by-laws of the corporation, shall be a necessary qualification to be a director of such corporation. 
\$24. Effect of Acceptance. Acting as such director, or knowingly permitting one's self to be named as such in the Agreement of Association, Articles of Organization, or in any prospectus, beforefiling the Articles of Organization with the Commissioner of Corporations, shall be conclusively held to be a contract on the part of such person with such corporation to take and pay for the necessary qualification shares, and the name of such person shall be entered as a member subscribing for such number of shares, and he shall be liable accoidingly. Accepting such office after incorporation shall have the same effect if the corporation has unissued shares sufficient to qualify such person or persons to be directors; and if not, failure for thixty days after such election, on the part of such person to become the bona fide owner of the requisite qualification shares, shall vacate the office.

$\S 25$. Oath. The directors shall take and subscribe the oath provided in section 33 .

\$20. Election. Unless otherwise provided the directors shall be chosen by the shareholders at the annual meeting; but if suitable provision is made in the Agreement of Association, where the corporation shall have more than one class of stock, or bonds with voting power, the right to choose part or all of the directors may be conferred upon the stockholders of any class or upon the bondholders to the exclusion of others.

\$27. Term. They shall hold office for one year, and until others. are chosen and qualified in their places; but such corporation may, by suitable provision in the Agreement of Association, classify. its. directors.in respect to their term of office, the classes to be as. nearly equal numerically as is possible, and no class to hold officefor less than one year (except those who may be elected at theorganization meeting), nor more than five years; and the term of office of at least one:class shall expire annually.

\section{Executive Committee.}

§ 28. Selection and Authority. Such corporation may by its by-laws. provide for an executive committee to be chosen by ballot from and by its board of directors. To such committee may be delegated the management of the current and ordinary business of thê corporation, and such other duties as the by-laws may prescribe.

\section{Officers.}

\$29. Enumeration of. Such corporation shall have a president, vice-president, registered agent, secretary, treasurer, and one or 
more auditors, and such other officers as 'may be provided for in the by-laws. The directors may appoint such other agents as may be necessary.

\$30. Qualification. The president and vice-president shall be directors. The registered agent shall be a natural person of full age residing within the United States, or a corporation organized, and having its place of business within the United States, and authorized by its charter to perform the duties of such an agent. The secretary and treasurer shall be bona fide owners of such number of shares as is provided in the by-laws, but in no case less than one share each, and the provisions of section 24 relating to ownership of shares by directors shall otherwise apply: No auditor shall be a director, but otherwise one person may hold two or more offices.

$\$ 31$. Election. The president, vice-president, secretary and treasurer shall be elected by the stockholders by ballot, tunless such authority is conferred on the directors by the by-laws. The auditor, or auditors, shall be elected by the stockholders by ballot. The first registered agent shall be chosen at the organization meeting, and his name shall be stated in the Articles of Organization, which shall be signed by him. The manner of choosing or appointing all other officers and agents may be prescribed by the by-laws, but in default of such provisions, such officers may be chosen by the board of directors.

\$32. Term. Unless otherwise provided in the Agreement of Association or in the by-laws, the officers, except as herein otherwise provided, shall be elected-annually, and shall hold their offices until their successors are elected and qualified. The registered agent may hold his office indefinitely, or until death, resignation, or temoval, and he shall be deemed to be such agent of the corporation until another is selected, and his selection is certified to the Commissioner of Corporations.

\$33. Oath. All such officers including the directors shall make oath that they will faithfully discharge their duties, and that they are the bona fide owners of the requisite unpledged qualification shares, "and such oath signed by such officers, and certified by the officer administering the same, under his hand and seal if he has one shall be filed and preserved with the corporate records.

$\S 34$. Bonds. The treasurer shall give bond for the faithful performance of his duties in such sum (not less than one thousand dollars), and with such surety or sureties as shall be prescribed in 
the by-laws. The auditor or each auditor, in a corporation having an authorized capital stock of one million dollars or over, shall give a bond of not less than one hundred thousand dollars, with one or more sureties for the faithful discharge of his duties; in corporations having a smaller authorized capital stock the bond of the auditor shall not be less than ten per cent thereof. The bonds of the treasurer and auditors shall be subject to the approval of the shareholders; but the provisions as to the bonds of auditors may be waived by the written consent of every shareholder.

$\S 35$. Effect of Failure to Qualify. Failure upon the part of any. one elected to qualify in accordance with the foregoing provisions in regard to ownership of stock, oath, or bonds, within thirty days after notified of his election shall render the office vacant, but not excuse from liability for acts done.

\section{Name.}

$\S 36$. Selection. Such corporation must have a name which shall be in English, and shall indicate that it is a corporation as distinguished from a natural person or partnership, and. shall also indicate whether it is a transportation, a transmission, or a trading corporation, or a combination of two of these as hereinafter provided.

\$ 37. Limitation. Such corporation shall not adopt as a part of its name the words "bank," "trust," "trust company," "savings," "investment," "insurance," "assurance," "loan," or "syndicate," or either of them, or similar ones. Such corporation shall not assume the name of any other company doing business within the United States, at the time of its organization, or within two years prior thereto, or a name so similar to that of any such company as to be mistaken for it; but a reorganized corporation may continue to use its own name; and the use of any name in violation of this. Act, may be enjoined at the suit of the Attorney-General of the United States or of a party having a prior lawful right to such name, in any court within the United States having equitable jurisciction, although a Certificate of Incorporation under such name may have been issued by the officer authorized to issue the same."

$\$ 38$. Change. The corporate name may be changed as provided in sections 92-94.

\section{Registered Office.}

$\S 39$. Necessity and Purpose. Such corporation shall have and keep cortinuously a registered office within the United States, which shall be deemed to be its post office address, and that of its officers 
and directors, to which and to whom all communications and notices, except notices of meetings may be addressed.

$\$ 40$. Location and Agent in Charge. The location of such office by town or city, street and number, if any, shall be set forth in the Agreement of Association. Such office shall be deemed to be at all times in charge of the registered agent, who shall, to all intents and purposes, and for all the purposes of this Act, be held to be the agent of such corporation for receiving such notices and communications.

$\$ 41$. Record of. Notice of the situation of such registered office, and of any change therein, shall be given to the Commissioner of Corporations, and recorded by him. Until such rotice is given the corporation shall not be deemed to have complied with the provisions of this Act with respect to having a registered office.

\section{Capital Stock.}

$\$ 42$. Necessity. Such corporation shall have such an authorized amount of capital stock, not less than ten thousand dollars, divided into transferable shares, of not less than ten dollars each, as may be stated in the Agreement of Association.

$\$ 43$. Classes. Such company may create and issue two or more classes of stock, with such designations, preferences, and voting powers, or restrictions or qualifications thereof, or restrictions upon the sale or transfer, as shall be stated in the Agreement of Association, and may increase or decrease the same, or any class thereof as is provided in section 95.

\$44. Redemption. Any class of stock may be made subject to redemption at not less than par, under such conditions and restrictions, and at such time and place as may be fixed in the Agreement of Association, provided, that at the time of redemption the debts and liabilities of the corporation shall not exceed the amount of the unredeemed capital of the corporation.

\$ 45. Issue of. (1.) Amount,-At least fifty per cent of the amount authorized shall be subscribed or taken, and at least ten per cent shall be paid, and certificate thereof filed before commencing business, as provided in section 81 ; the remainder thereof may be subscribed and paid at such times, and in such amounts as the needs of the corporation may require; but when the total amount is subscribed, and also when the total amount is paid, such facts shall be certified to the Commissioner of Corporations in the manner, and stating the things, required by section 81 . 
(2.) Consideration,-Stock may be issued in fulfillment of any contract of subscription or purchase, subject to payment in money, property, services, or expenditures, as hereinafter provided; but if otherwise than in money provision must be made therefor in the Agreement of Association.

$\$$ 40. Payment. Every share shall be deemed to, and shall, be held subject to the payment of its par value in cash, unless before the issuance thereof a contract shall be filed in the registered office of the corporation which shall truly and fully disclose in detail the real parties in interest, the parties to whom such stock is issied or to be issued, and the consideration therefor, whether the same be property, services, expenditures or otherwise. Such contract shall be open during regular hours to the inspection of any one, and a copy thereof shall be furnished by the registered agent to any one requesting who advarices the cost of copying at a rate not exceeding ten cents per one hundred words.

$\$ 47$. Issue of Stock and Bonds for Overvalued Property. Contracts of subscription to, or purchase of, stock, bonds or debentures, from the corporation or its representatives, before or after incorporation, whereby stock, bonds or debentures are to be issued at less than par value in exchange for inoney, property, services, or expenditures, or are to be paid in overvalued property, services or expenditures, shall be void, and such stock, bonds, and debentures, shall be deemed to be issued to such subscriber or purchaser, subject to the payment by him of the full par value in cash less the reasonable value of such property, services or expenditures, or other consideration received by the corporation. Such subscriber or purchaser, and the officers who authorize or issue the same shall be liable to the corporation, or any creditor, or the receiver, or a bona fide purchaser thereof for any damage sustained thereby.

$\S 48$. Judgment of Directors to Control. The judgment of the directors, acting in good faith, after full investigation, and exercised with the reasonable care of prudent business men, as to the fair value of such property, services, expenditures, or other consideration, received by such corporation, if all the provisions of this Act relating to such issue are fully complied with, shall be final and conclusive upon all parties; but not otherwise.

$\S 49$. Bonds with Voting Power. Any such corporation may issue bonds and debentures secured by mortgage or otherwise, with voting powers to the holders thereof equal to those of stockholders, if pro- 
vision is made therefor, and the conditions, circumstances, and manner of issuing the same are fully set forth in the Agreement of Association and are not otherwise inconsistent with the provisions of this Act.

\section{Shares.}

$\$ 50$. Nature of Shares. The shares of stock in every such corporation shall be personal property, in the nature of choses in action, and be considered goods, wares and merchandise within the provisions of statutes of frauds, but not otherwise. They shall be deemed to represent an interest in the franchise to be a corporation and to engage in national commerce under the provisions of this Act, granted by the government of the United States, and shall be subject to the control thereof, and exempt, except as herein provided, from any burden, control, or modification by the government of any other state.

\$ 51. Transferable. Unless otherwise provided in this Act or in the Agreement of Association, or amendments thereof, expressly making limitations upon the transferability of shares, such shares shall be transferable as hereinafter provided in section 158.

\$ 52. Certificates of Stock. (1.) Recitals in general,-Shares of stock shall be evidenced by a certificate of stock. Such certificate, shall specify the amount of the capital stock authorized to be issued by said corporation, the amount of each class, the amount of each class issued for cash, the amount of each class issued for other consideration, the par value of each share, the location of the registered office, and shall have written, printed, or stamped thereon the provisions as to the voting powers and preferences, and any limitation upon the right to transfer the same, contained in the Agreement of Association.

(2.) As to consideration,-Each certificate shall state whether it is issued for money, property, services, expenditures or other consideration, and whether it is fully paid or not. If not issued for money, such certificate shall have written, printed or stamped on its face a statement that it has been issued in accordance with a contract filed in the registered office open to inspection as provided in section 46.

(3.) As to payment, - If the stock is not fully paid at the time of its issue, there shall be written, printed or stamped upon each certificate thereof, "-_._ per cent paid up, balance payable as demanded by the directors," or otherwise, in accordance with the 
facits and terms of issue; and as further payments are made, the certificate shall be stamped accordingly.

(4.) Execution,-Each certificate shall be executed by the corporation in its corporate name, under the corporate seal, and signed by the President and Secretary, and certify the number of shares which it represents.

5.) Forgery of,-The provisions of section $\mathbf{5 4 1 5}$ of the Revised Statutes of the United States relating to forging and counterfeiting national bank notes shall apply to the forging or counterfeiting of the certificates, bonds, debentures, or other securities of corporations formed under this Act.

\section{By-lazes.}

$\S 53$. Necessity. Such corporation shall, subject to the provisions of section 71 of this Act, at the organization meeting, adopt bylaws for the management of. its property and the regulation of its affairs.

$\S 54$. Subjects that may be Regulated. The by-laws must be reasonable, consistent with this Act, and the laws of the United States, and may provide for the location of offices other than the registered office; the form, description, and custody of the corporate seal; the order of the issue, and the numbering of the certificates, and the record thereof; the registration and transfer of shares, and the surrender and cancellation of the old certificates; the issue of new certificates, including those issued in place of others lost or destroyed; the making of calls, the time of payment thereof, and the forfeiture or sale of shares for non-payment; the disposition of treasury stock; the-books and records to be kept and the custodians thereof; the time, place, calling, notice, quorum, conduct, parliamentary rules, order of business, and minutes of, and lists of shareholders, voting, and proxies at, stockholders' meetings; number, qualifications, classes, term, election, meetings, quorum, order of business, powers, duties, compensation, records, removals, resignations, and vacancies of directors; standing or executive committees and their duties; the enumeration, title, qualifications, selection, term, duties, compensation, removal, and vacancies, of offcers and agents; the closing of books before dividend and election days; the manner of declaring; notifying, and paying of dividends; the amount of working capital; the limits of indebtedness; theestablishment of reserve or sinking funds; the disposition of surplus; the place of deposit of funds; penalties, not exceeding twenty dollars, 
for the violation of such by-laws; and method of amending by-laws.

$\$ 55$. Effect. The shareholders and officers shall be bound by the provisions of the by-laws properly adopted, and shall be deemed to have knowledge of their contents. Third parties not having knowledge thereof shall not be affected thereby.

\$ 56. Power to Make. The power to adopt and amend by-laws shall be vested in the shareholders as provided in sections 71 , and 101.

$$
\text { IV. FORMATION. }
$$

$\S 57$. Steps to be Taken. The steps in the formation of such corporation include, or may include, the Preliminary Association, the Promotion, the Organization, the Incorporation, and Commencing Business.

\section{Association.}

§ 58. Incorporators. Any number, not less than seven, of natural persons, at least three of whom reside within the United States, and who are under no legal disability by the law of their domicile, may form a corporation under the provisions of this Act, for the purpose of engaging in national commerce.

\$ 59. Agreement of Association. Such persons undertaking to form such a corporation shall make and execute a written Agreement of Association which shall state-

(1.) Agreement,-That the subscribers thereto associate themselves with the intention of forming such a corporation.

(2.) Name,-The name assumed by such corporation.

(3.) Location,-The location by state, county, city, street and number if any, of the registered office.

(4.) Stock,-The total authorized amount of capital stock which shall not be less than shall, together with the bonds, debentures or other obligations proposed to be issued, be reasonably sufficient to accomplish the purposes for which the corporation is to be formed; and the Commissioner of Corporations shall not approve, nor shall the Secretary of Commerce and Iabor issue a Certificate of Incorporation, upon organization papers in which the amount of authorized stock stated shall appear altogether inadequate to accomplish the purposes of said corporation.

(5.) Stock to be issued, - The amount of capital stock which is then to be issued, with which to commence business and which shall not be less than fifty per cent of the amount authorized. 
(6.) . Minimum subscription,-The minimum amount of stock to which subscription or purchase then is, or is to be, invited, and which shall be reckoned exclusively of any amount payable otherwise than in money. If no amount is named, it shall be.presumed to be the amount with which it is proposed to commence business.

(7.) Number of shares, - The number of shares into which the authorized capital stock is to be divided, and the par value thereof.

(8.) Classes of stock, - If there are to be two or more classes of shares, or bonds or debentures with voting power are to be issued, the amount and description of each, with a statement of the terms, conditions and preferences, upon which they are to be created, issued, held or voted upon.

(9.) Restrictions on transfer, - If any restrictions are to be placed upon the transfer of any shares or any class of shares, other thar herein provided, the same shall be fully set forth.

(10.) Redemption of stock,-What, if any, class of stock shall be subject to redemption, and if any, the amount, method, and date thereof.

(11.) Directors, - The number of directors; and if they are to be classified as to their terms of office, or any of them are to be elected by particular shareholders or bondholders, the classification and the conditions thereof shall be specified.

(12.) Nature of business, - The nature of the national commerce in which such company proposes to engage, specifying whether the same is to be a transportation, transmission, or trading corporation, or more than one of these, subject to section 85 (8).

(13.) Transportation, - If the same is to be a transportation, or transmission corporation, there shall also be stated the nature and character of the work to be constructed, purchased, leased, owned, maintained, operated, or controlled, in any way directly or indirectly, together with the names of the terminal places thereof, the states and counties into or through which it passes or is to pass, and the principal cities reached thereby. Also, whether or not such corporation proposes to exercise the power of eminent domain. Also the method or methods, or the means of propulsion, or forces or devices used or to be used in conducting or carrying on such transportation or transmission business. Also whether or not such corporation proposes to engage in or carry on, domestic transportation or transmission, within the states through which its lines may be constructed, subject to the laws of such states. 
(14.) Trading, - If the same is a trading corporation, the nature of the trading to be carried on, together with the location, character and description of any business, plant, factory, farm, or establishment of any kind whatever, to be constructed, purchased, leased, owned, maintained, operated, or controlled in any way directly or indirectly, by or in connection with, or as producing, or requiring the products or materials dealt in, or to be dealt in, by such trading corporation.

(15.) Otherbusiness, -The nature, location, and description of any other business, plant, factory, farm, or establishment of any kind whatever to be engaged in, owned, maintained, operated, or controlled, in any way directly or indirectly, by or in connection with such corporation.

(16.) Other provisions,-Any provision which the incorporators may choose to insert for the regulation of the business, the conduct of the affairs, the plan of the financial organization, or the government of the corporation, or defining, limiting or regulating the powers of the same, or the stockholders, or any class thereof, or the directors, not inconsistent with the provisions of this Act or of the Constitution and laws of the United States; but if such provisions are not so set forth in the Agreement of Association or an amendment duly made thereto, they shall be void and of no effect.

(17.) Duration,-The duration of the corporate life, which shall not be more than 100 years.

(18.) Names of signers, - The names and post office addresses of those who sign this Agreement of Association, (hereinafter called incorporators), the number and class of shares, bonds or debentures subscribed for by each, which shall not be less than one share by each, and not less than three thousand dollars in all.

$\$ 60$. Execution of Agreement. The agreement of Association shall be signed in person by the incorporators named therein, who shall acknowledge the same before a judge of some court of record, or a notary public, and a certificate of such acknowledgment under the seal of the court or officer, taking the same, shall be attached thereto.

$\S 6$. Functions of Incorporators. Without excluding others who forward or participate in the formation of the corporation, the incorporators shall be deemed promoters, and until the holding of the organization meeting, may have direction of the affairs and the organization of the corporation, and may take steps not inconsistent with 
this Act to secute the proposed issue, subscription or purchase of the stock of the corporation, and subject to the provisions of section 63 such-agreements, contracts and engagements thereof shall be binding upon the corporation.

\$ 62. Subscription and Allotment. Without excluding other methods of application or subscription made before or after incorporation, books may be opened by the incorporators or directors, for receiving subscriptions to the shares, bonds or debentures, at such time and place, and upon such notice as they may deem expedient; the names and addresses of the subscribers with the amount of the subscription of each shall be entered therein; when the minimum subscription provided for in the Agreement of Association is obtained the organization meeting may be called as provided in section 70. If more than the minimum subscription is obtained, the incorporators or directors may make allotment among those that have applied as they, in their discretion, deem to be for the best interests of the corporation. Notice of the allotment made shall be given immediately, personally, or by mail postpaid, to those to whom shares have been allotted.

\section{Promotion.}

$\S$ 63. Prelimirrary Promotion Agreements. Every promoter is in a fiduciary relation towards the corporation which he is engaged in promoting. He may not sell or let his property, or property in which he has an interest, to the corporation, and may not be interested in any contract with the corporation, unless at a general meeting of the shareholders of the corporation before the completion of the purchase, lease, or contract a full and fair disclosure is made that he is the vendor or lessor or has an interest in the property. or in the contract, and of the nature and amount of that interest. Any such contract as aforesaid with respect to which such disclosure is not made shall be voidable at the option of the corporation. A promoter may not retain for his own use any profit or remuneration whether in money, shares or otherwise, arising out of, or received by him in connection with, the promotion of the corporation or in consideration of services rendered by him in the course of such promotion, unless at a general meeting of the corporation full and fair disclosure has been made of the nature and amount of that profit or remuneration, and the corporation has by formal resolution assented thereto after such disclosure. Every promoter shall be liable to account to the corporation for the amount or value of any 
secret profit or remuneration, and to repay the same to the corporation with interest as the court may direct. Subject to the foregoing, and the provisions of sections 45 to 48 , and 81 to 83 , the agreements, contracts and engagements of the promoters, shall, when accepted, adopted, ratified or acted upon with full knowledge of their provisions by said corporation, become binding thereon as of the date when made by the promoter.

$\S 64$. Prospectus to be Issued. If the public is or is to be invited to subscribe for, or purchase, any part of the stock, bonds, or debentures proposed to be issued by such corporation, a prospectus of said corporation shall be prepared and issued under the circumstances and conditions following.

\$ 65. Definition of Terms. (1.) Prospectus shall include every prospectus, announcement, circular, advertisement, or notice of every kind whatever issued in any manner or form whatever, by or on behalf of any corporation organized, or to be organized, or by or on behalf of any person engaged or interested in the formation of such corporation, under this Act, with a view of obtaining, or directly or indirectty inviting subscriptions to, or purchase of, shares, bonds, or debentures, in such corporation, except such as may be issued to and invite only existing members of such corporation to subscribe for further shares, bonds, or debentures.

(2.) Vendor Shall include every person who has entered into any contract, absolute or conditional, for the sale, purchase, letting or subletting, or for any option therefor, of any property to be thereby acquired by the corporation, when the purchase money is not fully paid at the date of the issue of the prospectus, or any part of such purchase money is to be paid by, or out of the proceeds of, the subscription invited by the prospectus, or the fulfilment of the said contract in any way depends on such subscription, or the results thereof.

(3.) Material fact,-Eivery contract or fact which relates to the corporation or its affairs, or the promoters, vendors, officers, or the subscription, is to be deemed to be material, if it would influence the judgment of a prudent investor in determining whether he would participate in the subscription invited by the prospectus unless such contract was made, or fact occurred, more than two years before the issue of such prospectus.

$\S 66$. Contents of Prospectus. Every prospectus shall state:-

(1.) The contents in full of the Agreement of Association. 
(2.) The number of shares fixed as qualifications of a director, if different from amount provided in section 23.

(3.) As topromoters, - The names and addresses of the promoters and directors or proposed directors; the number of shares, bonds, or debentures held or agreed to be taken by them respectively, and whether wholly or partly paid up; also full particulars of the nature and extent of the interest, if any, of every director or proposed director in the promotion of, or in the property acquired or to be acquired, by the corporation.

(4.) As to preliminary expenses, - The total amount or estimated amount of preliminary expenses connected with the formation of the company, issuing the shares, bonds, or debentures, specifying particularly the total fees to be paid to the government; the total fees for legal and expert services; the total cost of preparing, printing, circulating and advertising the documents used or to be used in launching the corporation; the total amount paid or to be paid in any way by any person on behalf of the corporation to incorporators, promoters, or directors, for becoming, such, or to qualify them therefor, or for services.performed or to be performed by any of them,or for them, in the formation of the corporation; the total ainount of reward, remuneration, or commission with the rate thereof paid, or to be paid to any one for subscribing, or agreeing to subscribe, or procturing, or agreeing to procure, subscriptions to, or purchase of, or underwriting or guaranteeing the sale of, shares, bonds, or debentures; the total amount of fees, charges, or commissions with the rate thereof, paid or to be paid to any one in connection with the acquisition of any kind of property for or on behalf of the corporation; any other expense incurred or to be incurred in the formation of the corporation, and to whom paid or to be paid, and for what purpose; and if any of said sums, or any part thereof, is to be paid in shares, bonds, or debentures, the same shall be su indicated, and the face value thereof given.

(5.) As to stock, - The minimum subscription upon which the directors will allot the shares, bonds, or debentures subscribed for, and proceed with the issue thereof; the minimum amount payable on application and allotment on each share, bond, or debenture; the number and amount of founders or management shares, if any, and the nature and extent of the interest the holders thereof are to have in the property and profits of the corporation; the number and amount of shares, bonds, or debentures issued or to be issued to 
any one, as fully or partly paid up otherwise than in money, and in the latter case the extent to which they are so paid up, and in either case the consideration for which and the person or persons to whom such shares, bonds, or debentures have been issued, or are proposed or intended to be issued; the amount reserved or to be reserved for working capital; the application or proposed application of the remainder of the issue or proposed issue of the shares, bonds or debentures, to which subscription is invited. And in case of a second or subsequent offer of shares, bonds, or debentures, or invitation to subscribe therefor, the amount before offered for subscription on each previous allotment, with the amount actually allotted, and the amount paid thereon.

(6.) As toproperty to be acguired,-The names and addresses of the vendors of any property purchased or acquired by the corporation, or to be so purchased or acquired, which is to be paid for wholly or partly out of the issue or proceeds of the issue offered for subscription by the prospectus; a brief description of the nature of such property, and its location, if physical property, and whether any part, and if so, how much, is considered franchise or good will; the consideration paid or to be paid therefor, specifying whether any and how much is or is to be in cash, shares, bonds, or debentures, and to whom paid or to be paid, and what part is for franchise or good will; and where there are more than one vendor, or the corporation is a sub-purchaser, the amountpayable in money, shares, bonds, or debentures to each vendor, separately stating the sums paid or to be paid to each for franchise, or good will, and for other property; also the dates of such purchase or acquisition; and in case such property has been valued or appraised by any one with a view of purchase by the company the names and addresses of such appraisers, with the date of the appraisement.

(7.) As to contracts, - The dates of and the names of the parties to, any material contract directly or indirectly relating to the corporation or to the promotion thereof entered into by the corporation, or incorporators, promoters, directors, or any person for or on behalf of it or them or any of them, with any of them or with any other person whomsoever, within two years before the issue of such prospectus, whether subject to adoption by the directors or otherwise; also a reasonable time and place (which shall be the registered office of the corporation if it is organized), where such contract, if in writing, may be inspected by any one interested; but this shall 
not apply to contracts entered into by the corporation after authorjzed to commence business, in the ordinary course of business, unlesș shares, bonds, or debentures are to be issued as a consideration or part consideration therefor.

(8.) The names and addresses of the auditors or proposed auditors, if any, of the company.

§. 67. Signing and Filing Prospectus. Eivery prospectus shall be signed by every person named therein as a director or proposed director of such corporation, and shall be filed with the Commissioner of Corporations on or before the date of its issue, which date, together with the date of filing, shall be stated on the face of said prospectus; and said prospectus shall not be received and filed by said Commissioner unless it is so signed and dated.

§68. No Haiver of Conditions Valid. Any condition requiring or binding an applicant for shares, bonds or debentures to waive, and any agreement to waive due compliance with sections 64,65 , and 66 , or purporting to affect him with notice of any 'document, contract or matter not specifically referred to in the prospectus shall be void.

$\S 69$. Effect of Failure to Comply. Every prospectus which does not comply with the provisions of sections 64 to 68 , above, shall, if knowingly or negligently issued by them, be deemed fraudulent on the part of every promoter, incorporator, director, or manager who is such at the time of issuing the prospectus, and also every person who is, by his authority or consent, named in the prospectus as, or as having agreed to become, a director of the corporation. Such parties, or any of them, shall be liable to make compensation to to any person aggrieved by such defective prospectus, unless such party proves that the matter not disclosed by the prospectus was unknown, and could not with reasonable diligence have been discovered by him, or the same was due to an honest mistake of fact, or the aggrieved person had actual notice and knowledge of the undisclosed matter. Any person subscribing for or taking shares, borids, or debentures on the faith of such defective prospectus shall, unless he has actual knowledge of the facts omitted, be entitled to rescind, or sue for rescission of his subscription. Nothing herein shall limit or diminish any liability which any person may incur under the general law apart from the provisions of this section.

Promoters, officers, directors, and agents violating the foregoing provisions shall be subject to the penalties imposed in section 181 . 


\section{Organization.}

\$ 70. Notice of Orǵanization Meeting. A written or printed notice stating time, place, and purpose, of the organization meeting signed by at least three of the incorporators shall, at least ten days before the time fixed for such meeting, be given to each incorporator, and to each one with whom a contract to take shares exists, either by delivering such notice to him, or mailing it, postage prepaid, addressed to him at his residence or usual place of business; and the affidavit of one of the signers of such notice stating how, when, and to whom such notice has been given, shall be filed and recorded with the records of the corporation. But if all those entitled to notice shall in writing indorsed upon the Agreement of Association waive such notice and fix the time and place of meeting, no notice need be given.

$\S 7$. Business of Organization Meeting. At such meeting a quorum shall consist of a majority of shares contracted to be taken, whether by subscription, application and allotment, or otherwise, and each share, unless otherwise provided in the Agreement of Association, shall be entitled to one vote; a temporary chairman and a secretary shall be chosen by ballot; by-laws, 'which shall be expressed in separate articles and paragraphs, properly numbered, shall be adopted; directors, and such other officers as may be required, unless the by-laws shall otherwise provide, shall be elected by ballot, to hold office until the first annual meeting is held, and their successors are elected and qualified, but the president shall be elected from among the directors. The temporary secretary shall make and attest a record of the proceedings of such meeting, including a copy of the by-laws, and the names of the directors and officers elected, and the same shall be filed and kept as a part of the records of the corporation.

\$72. Officers to Qualify. Each original director and officer, before entering upon the duties of his office, shall, unless he has already done so, sign the Agreement of Association, and indicate thereon the shares which he agrees to take and pay for as other subscribers, and which shall in no case be less than the amount of qualification shares required to hold such office; each original director and officer, shall, also before entering upon his duties, take the oath required by section 33 .

$\S$ 73. Other Officers to be Chosen. If the by-laws provide for the election of any of the officers by the directors they shall, forthwith, 
hold a meeting for that purpose, and the record thereof shall be preserved with the records of the corporation.

$\S 74$. Articles of Organization. The directors, or a majority of them, who are elected at the organization meeting, together with the President, Secretary and Registered Agent, shall forthwith, make, sign and make oath to Articles of Organization, setting forth truly:-

(1.) A copy of the Agreement of Association, with all the signatures thereto, and the indorsements thereon.

(2.) The date of the organization meeting, and of successive adjournments thereof, with the names of the temporaiy chairman and secretary.

(3.) A copy of the by-laws adopted.

(4.) A list of the names of the officers and directors elected, with their residences and post office addresses.

(5.) The amount of capital stock which is to be paid for in money.

(6.) Whether such capital stock is to be paid for in whole or in part before the corporation commences business, and if in part, the amount of the instalments. But at least ten per cent of the authorized capital stock shall be paid for before commencing business.

(7.) The amount of capital stock to be paid for in property and if tangible property, its location, quantity, and description, and the amount of stock issued or to be issued therefor; and if intangible, whether patents, copyrights, franchises, good will, choses in action, or other kind, a full description thereof with the amount of stock issued or to be issued therefor.

(8.) The amount of capital stock to be issued or paid for in services or expenses, with a description of the nature of such services or expenses and the amount of stock issued or to be issued therefor.

\section{Incorporation.}

$\S 75$. Approval and Filing of Articles. The Articles of Organization shall be submitted to the Commissioner of Corporations, who shall examine the same, and may require such additional information given, and such amendments made, as he may deem necessary. When the Articles of Organization are made to conform to the provisions of this Act, the Commissioner of Corporations shall so certify and indorse his approval thereon, with the date thereof, and thereupon the Articles of Organization shall, upon the payment of 
the fees provided in section 80 , be filed and kept in the office of the Secretary of the Department of Commerce and Iabor, who shall indorse thereon the date of such filing, and the fees paid therefor.

$\S 76$. Issue of Certificate of Incorporation. Said Secretary shall thereupon issue a certificate of incorporation, in the following form:-

\section{CERTIFICATE OF INCORPORAMION.}

Whereas, on the .- day of _- in the year A. D., ...., there were filed in this office Articles of Organization for the purpose of forming a corporation to engage in national commerce, in the words and figures, with all the indorsements thereon, except the by-laws adopted, as follows, to-wit: (copy in full of the Articles of Organization except the by-laws).

Now, therefore, I the Secretary of the Department of Commerce and Irabor do hereby certify that the incorporators above named and their associates and successors are legally organized and established as, and are hereby made, an existing corporation under the name of with the powers, rights, and privileges, and subject to the limitations, duties, and restrictions, which by law appertain thereto.

Witness my official signature hereunto subscribed, and the seal of the Department of Commerce and Labor affixed this -- day of -in the year

[SEAT]

Secretary of Department of Commerce and xabor.

\$ 77. Record of Certificate. Such Certificate of Incorporation shall be recorded at length in the office of said Secretary in books kept for that purpose, and the same, together with the Articles of Organization, including the by-laws shall be kept indexed in such manner that they may be readily referred to. Such documents shall be deemed public documents and shall be open to inspection and copying as are other public documents, and certified copies thereof shall be furnished to those who apply therefor upon payment of the cost thereof at not to exceed twenty-five cents per folio of one hundred words.

$\$ 78$. Delivery and Effect of the Certificate. Such certificate shall be delivered to said corporation and shall have the force and effect of a special charter, and it, or the record thereof, or a certified copy, or a printed copy of the-same, as hereafter provided, shall be con- 
clusive evidence of the existence of such corporation from the date of filing of the Articles of Organization with the said Secretary.

$\$ 79$. Publication of Certificate. The said Secretary shall from year to year or oftener, cause to be printed in pamphlet form ten thousand copies of the Certificates of Incorporation issued by said office during the preceding year or part of year; such copies shall be distributed to the parties, and in the numbersprovided by section 73 of the Act of Congress of January 12, 1895, chapter 23, for distributing the bound copies of the Statutes at Iarge, except there shall be kept for the use of the Department of Commerce and Iabor, such number of copies as the Secretary thereof may designate as necessary, the balance, after supplying the parties indicated in said section 73 to be kept by said Secretary of the Department of Commerce and I abor, to be disposed of to such persons as may wish them, at the cost price thereof, the receipts therefor to be accounted for and paid over as other receipts by such department are.

\$ 80. Fees. (1.) On filing the Articles of Organization in the office of the Secretary of the Department of Commerce and Iabor, the incorporators shall pay to said Secretary, before he accepts said Articles, the following fees, for the use, and to be paid to the Treasurer, of the United States:-

Twenty cents on each one thousand dollars, of capital stock authorized for the first one hundred millions or under, but in no case less than twenty-five dollars.

Twenty-five cents per one thousand dollars for the second one hundred millions, and so on at a rate per one thousand dollars, increasing five cents for each additional one hundred million dollars, of capital stock authorized. ${ }^{1}$

\footnotetext{
1 NorE:-It will be seen that the fees provided herein increase as the authorized capital stockincreases; this for two reasons, first, large franchises are more valuable to the holders, and second, more dangerous to the public. The fees herein provided would be as follows:-

A corporation with a capital stock of:-

\begin{tabular}{|c|c|c|c|c|c|c|}
\hline 125,000 & 80u & Day $\$$ & \multicolumn{4}{|c|}{$\$ 400,000,000$ would pay $\$ 110,000$} \\
\hline 500,000 & "t & 100 & $500.000,000$ & $\bullet$ & & 150,000 \\
\hline $1,000,000$ & “ & 200 & $600,000,050$ & “ & “ & 195,000 \\
\hline $5,000,000$ & “ & 1,000 & $700,000,000$ & “ & 18 & 245,000 \\
\hline $10,000,000$ & “ & 2,000 & $800,000,000$ & • & 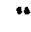 & 300,000 \\
\hline $200,000,000$ & “ & 20.000 & $900,000,000$ & “ & “ & 360,000 \\
\hline $200,000,000$ & " & 45,000 & $1,000,000,000$ & * & “ & 425,000 \\
\hline $300,000,000$ & “ & 75,000 & $1,100,000,000$ & “ & “ & 495,000 \\
\hline
\end{tabular}

The latter is the amount of the capital stock of the United States Steel Corporation; the amount that corporation had to pay to the State of New Jersey, as an incorporation fee, was $\$ 220,000$; in Mlichigan the fee would have been $\$ 550,000$; in Ohio, $\$ 1,700,000$; in Penusgivania, $\$ 1,375000$.

The same method is applied to the franchise tar provided for in section 148, and for the same reasons.
} 
(2.) For increase of capital stock, or merger, or consolidation of corporations, such sum as would have been required had the original capital stock been the same as the total stock, new and old after the increase, merger or consolidation, less what was paid upon the original, or any former increase, but in no case less than twenty dollars.

(3.) For extensions or renewals of corporate existence twentyfive dollars.

(4.) For all other certificates or notices to be filed in said office, under this Act, ten dollars.

\section{Commencing Business.}

$\$$ 81. Filing Statement as to Subscription and Payment of Stock. No such corporation shall commence the business for which it is organized, or exercise any borrowing powers, except such powers as may be necessary to complete its organization in accordance with the Certificate of Incorporation unless at least fifty per cent of the authorized capital stock of the corporation has been, in good faith, subscribed or agreed to be taken unconditionally and unless ten per cent of such authorized capital stock has actually been paid in to the corporation, and unless it shall submit to the Commissioner of Corporations a written statement, signed and verified under oath, by the president, secretary, and a majority of the directors, certifying that such subscription and payment have been made and setting forth therein the following: (1.) The amount of the authorized capital stock, and the number of shares, with the par value thereof. (2.) The amount of each class of shares subscribed for or issued. (3.) The amount paid thereon in cash. (4.) The amount paid for otherwise than in cash, and the character, description, and location of the consideration received therefor. (5.) The amount unpaid on shares not paid for in full. (6.) The name, residence, and address of each shareholder, with the number, class, and amount of shares owned by each, the amount paid thereon, and the method of payment.

$\$ 82$. Certificate to Commence Business. Upon submitting the same to the Commissioner of Corporations he shall examine the same, and if found correct, he shall so certify thereon, with the date thereof, and thereupon such statement shall, upon the payment of the fees required, be filed and kept in the office of the Secretary of the Department of Commerce and Iabor, who shall indorse thereon the date of such filing, and the same shall be recorded and 
indexed, and be subject to inspection and copying as are the Certificate of Incorporation and by-laws. The Secretary of the Department of Commerce and Labor shall thereupon issue, under the seal of his office, to such corporation a Certificate to Commence Business, stating that the provisions of this Act relating to commencing business have been complied with, and the provisions of this Act in regard to recording, indexing, inspecting, copying, certifying, printing, distributing and keeping in the registered office of copies of the Certificate of Incorporation shall apply to the Certificate to Commence Business.

\$. 83. Commencing Business Without Authority. (1.) Any contract made by such corporation before the date at which it is entitled to commence business shall be provisional only, and shall not be binding on such corporation until that date, but shall, if otherwise properly executed, become binding on that date.

(2.) If any such corporation shall commence businees or exercise borrowing powers contrary to the foregoing provisions, every person who is responsible therefor shall be personally liable on such contracts, and liable to the penalties provided in section 181 .

(3.) Nothing herein, however, shall prevent the simultaneous subscription of any shares and bonds and debentures, or the receipt of any application therefor.

(4.) Such corporation mas be prevented by injunction or quo warranto, as provided in sections 149-152 from continuing such business, and be subject to the penalties provided in section 180 .

$\S 83$ a. Failure to Begin Business. If any corporation organized under this Act shall fail for three years after incorporation to commence in good faith the business for which it was incorporated, it shall be deemed to have forfeited all its rights, privileges, and franchises, -and may be wound up without decree of dissolution.

\section{POWERS.}

\section{In General.}

\$84. General Powers. Such corporation shall have, subject to the provisions of this Act, the following genèral powers, without specially setting them forth in the Agreement of Association.

(1.) Succession, - To have succession by its corporate name, for the period not exceeding 100 years, specified in the Agreement of Association, after the date of filing the Articles of Organization in the office of the Secretary of the Department of Commerce and Irabor. 
(2.) Officers, - To appoint or elect such officers and agents as its business shall require; define their duties and require security for the faithful performance thereof; fix their compensation; remove or dismiss them at pleasure, and appoint others in their stead.

(3.) Seal,-To have and use a common seal, and alter the same atpleasure, but such seal shall have the corporate name, the year of incorporation, and the location of its registered office engraved upon it in legible English characters.

(4.) Contracts and mortgages, - To make contracts, incur liabilites, and borrow money on its credit, and for its use, and execute and deliver any form of instrument or security therefor, that its purposes may require, subject to the provisions of this Act, and particularly sections 89,90 .

(5.) Property, - To acquire by grant, gift, purchase, devise or bequest, to hold, use, convey, lease, mortgage, pledge, or dispose of, any such property, real or personal, tangible or intangible, or any estate or interest therein, and any rights or claims thereon, therein, or thereto, and wheresoever located, as the business of the company may require, subject to the provisions of this Act.

(6.) Suits, - To sue and be sued in its corporate name, as provided in section 88 .

(7.) $B y$-laws, - -To make by-laws regulating the matters set forth in section 54, and amend the same as provided in sections 94, 101.

(8.) Forfeit shares, - To forfeit the shares of delinquent shareholders for non-payment of calls as provided in section 91 .

(9.) Amendments,-To amend its Agreement of Association, Articles of Organization, or by-laws, or.Certificate of Incorporation, as provided in sections 92 to 94 .

(10.) Change stock,-To increase or decrease its capital stock or any class thereof as provided in section 95.

(11.) Consolidate,-To consolidate with other corporations, as provided in sections 96 to 98.

(12.) Sell out,-To sell or otherwise dispose of all its corporate property and franchises as provided in section 99.

(13.) Dissolve, - To wind up its affairs, surrender its charter, dissolve itself or be dissolved and have its affairs wound up as provided in sections 185 to 193.

$\$ 85$. Special Powers. And also subject to the provisions of this Act, such corporation may have the following special powers if 
the same are claimed, and the details thereof are expressly set forth in the Agreement of Association, or an amendment thereto duly made and filed, but not otherwise.

(1.) Classify stock,-To classify its stock as provided in section 43.

(2.) Stock for property, -To issue its stock for property, services, or expenses as provided and limited in sections 45 to 49 .

(3.) Voting bonds, - T'o determine whether, and to what extent, bonds may be issued with voting power as stated in section 49 .

(4.) Voting, - To determine what number of shares shall entitle the shareholders to one or more votes, if otherwise than ope vote for each share owned.

(5.) Cumulativie voting, - To provide for any plan of cumulative or proportional voting.

(6.) Quorum,-To determine what number; other than a majority, of shares outstanding, or the number of shareholders, shall constitute a quorum.

(7.) Transfer of shares, - To provide for limiting the transferability of shares.

(8.) Businiess,-To engage in such branch, or branches, of national commerce anywhere, either in or out of the United States, as shall be specifically designated in the Agreement of Association; but no trading corporation shall be formed with, or shall have, the power to engage in or carry on the transportation business; nor shall a transportation corporation be formed with or have the power to engage in or carry on a general trading, producing, farming, mining, or manufacturing business of any kitid; but either a transportation or trading corporation may be formed with the power, if set forth in the Agreement of Association, of engaging in the transmission business.

(9.) Eminent domain,-In case of a transportation or transmission curporation, to exercise the power of eminent domain, so far as may be necessary, and no farther, to carry out its transportation or transmission purposes, subject, in all cases to the provisions of the laws of the state where the property sought to be appropriated is situated, so far as the same are not in conflict with this Act; but in all cases full compensation for the property so to be taken must be paid, or secured, before possession thereof is taken. Also to use such method, or methods, forces or devices for condricting such transportation or transmission business as may be partic- 
ulariy set forth in such Agreement of Association. Also, subject to the control of the state or country where exercised to engage in or carry on domestic transportation or transmission within such state or country.

(10.) Other lines of business, - In case of a trading corporation, and as incidental to its purpose of carrying on national commerce, to engage in the growth, production, mining, or manufacturing of the products which form the subject matter of its national commerce, anywhere, either within or without the United States, provided the power to do so, the method of doing so, the business proposed to be done, and the location or locations thereof, are specifically set forth and fully described in the Agreement of Association; but such part of the business of such corporation shall be subject to the laws of the state or country wherein such business is located or carried on.

$\$ 86$. Implied Powers. Such corporation shall have such other powers as are reasonably necessary to the full and complete exercise and enjoyment of the foregoing general or special powers, or such others as are conferred, or as are necessary for the full performance of the duties imposed, upon such corporation by this Act.

\$ 87. Powers Prohibited. (1.) General,-No such corporation shall possess or exercise any other powers than those herein granted.

(2.) Banking, etc., - No such corporation shall engage in any banking, insurance, trust, investment, real estate, or professional business, or busines similar thereto.

(3.) Accommodation contracts, - No such corporation shall become a maker, indorser, surety or guarantor of, or upon any contract except such as may be necessary in carrying on its business, and then only for a full consideration received therefor. Any officer or agent violating this provision shall become personally liable thereon to an innocent holder of such instrument, and liable to the corporation as provided in section 168.

(4.) Partnerships, - No such corporation shall enter into any partnership arrangement of agreement of any kind, but this shall not prevent the making, by transportation or transmission corporations, of contracts with connecting carriers, subject to the provisions herein, for a through rate of transportation or transmission, to be divided as may be agreed upon.

(5.) Trade combinations, - No such corporation shall enter into, or become a party to, any trade combination, pool, contract in restraint of trade or competition, conspiracy, combination, trust, or 
monopoly, contrary to the provisions of the National Anti-trust Acts; the Interstate Commerce Act, or Department of Commerce Act, or the amendments to either of the same, or as to any business carried or by such corporation within any state, which is not national commerce, contrary to the Anti-trust Acts of any state in which sich business shall be done. The individual acts of the shareholders, or a majority thereof, whether done through the ordinary forms of corporate action or otherwise, having such effect, shall be held to be the act of strch corporation.

(6.) Acquisition of its own shares,-No such corporation shall purchase or acquire directly or indirectly its own shares except to Iedeem the same in the manner expressly provided in the Agreement of Association, and subject to sections 44, 95, herein, or except in case of seizure, forfeiture, or sale, in order to secure payment for the same as provided in section 91 , herein, or by purchasing the same in an execution or attachment sale, in order to secure the payment of a bona fide debt due the corporation, previousiy incurred, when no other property of the debtor subject to execution, or attachment and sale, can be found; but such stock shall be sold within one year from the time it is so purchased.

(7.) Acquisition of shares in other corporations, -No such corporation shall subscribe for, purchase, or directiy or indirectly otherwise acquire the shares of any other company, except by way of purchase upon execution or attachment sale in order to secure the payment of a bona fide debt due such corporation previously incurred, when no other property of the debtor subject to execution or attachment and sale can be found; or except in completing a contract of merger or consolidation in compliance with sections 96 to 98 .

(8.) Register other corporations as shareholders, - No such corporation shall permit to be registered on its books, or shall recognize as the owner of its shares and entitled to vote or receive dividends thereon, or shall receive the vote of, or pay dividends to, any company formed under the laws of any state or country whatever, which has purchased or in any way acquired the control over a majority of the shares of 'such corporation, or by way of voting trust or otherwise actually exercises control over the selection of the board of directors, or a majority thereof, or over the management of such corporation, unless such company has complied with and been organized under the provisions of this Act, and become in every way subject thereto, and then only in completion of a con- 
tract of merger or consolidation in compliance with sections 96 to 98 .

(9.) Preference of creditors, - No such corporation shall directly or indirectiy, in contemplation of insolvency, bankruptcy or winding up of its affairs, prefer any of its creditors, and all attempts to do so, shall be void and of no effect, and the provisions of section 60 of the Bankruptcy Act of July 1, 1898, and the amendments thereto shall apply to such attempts.

(10.) Loan money to shareholders, - No such corporation shall loan money to any shareholder to enable him to withdraw in effect any part of the money paid in by him on his stock, nor shall make or declare dividends, except from the surplus or net profits arising from its business, nor divide, withdraw, or in any way pay to the stockholders, or any of them, any part of its capital stock, or reduce its capital stock, except as provided in sections 44, and 95.

(11.) Interpretation, - The foregoing enumeration of limitations upon the powers of such corporation shall not be so construed as to imply the grant of other powers not expressly excluded.

\section{Particular Powers.}

$\$$ 88. Suits. (1.) Place, -Such corporation may sue in its corporate name in any court of law or equity, anywhere, having jurisdiction of the subject matter and of the defendant.

Suit may be brought against stich corporation in the courts of any of the states or territories, or of any foreign country, or in the federal courts in any district, having jurisdiction of the subject matter, and wherein the defendant has an established place of business. The circuit courts of the United States shail have general jurisdiction to determine controversies arising under this Act without regard to the amount involved, and if necessary, process may be made to ran throughout the United States. Appeals may be prosecuted as provided in section 152.

(2.) Citizenship,-Such corporation shall be deemed to be, for the purposes of jurisdiction, a citizen of the state in which its registered office is located; but it shall not be considered a non-resident os foreign corporation within the meaning of state attachment laws.

(3.) Service of process,-Service of writs or process may be made upon such corporation by the officer authorized to serve the same, leaving a duly certified copy thereof, personally with the agent or person in charge of such place of business, or by said officer mailing, postage prepaid, by registered letter, a certified copy of such writ or process, addressed to the registered agent at the registered 
office of the corporation, in which case the officer so serving such writ or process shall certify in his return that he made service in this way specifying the dates and details thereof, and shall attach thereto the postal receipt showing the same to have been sent to, and the return postal receipt showing the same to have been received by, such registered agent, or at such registered office, and such return, so made, shall be conclusive evidence of the due service of said writ or process upon such corporation at the date of such return postal receipt, and shall justify a judgment in personam against.such corporation. In case no such return postal receipt is received before the return day, an alias, and a pluries writ may be issued and served in like manner, or upon failure to obtain service in this way, service may be made by publication or otherwise, in accordance with the law of the place where stit is brought.

\$ 89. Contracts. (1.) Execution,-Contracts; which if made between natural persons would so far as the form is concerned, be valid, shall, subject to the provisions of this Act, be valid if made in the same manner in the corporate name, by any person acting under the express or implied atuthority of such corporation, whether the same be by parol, in writing, or under seal.

(2.) Seal,-The corporate seal need not be affixed to any contract or conveyance, except such as if executed by a natural person would be required to be under seal. The presence of the corporate seal upon other documents shall not give them a legal effect different from what they would have without the seal. When the corporate seal is present upon a document purporting to be executed by the corporation it shall be prima facie presumed to have been regularly affixed by proper authority. An impression of the corporate seal stamped upon the document itself, without wax or wafer, shall be a sufficient sealing of any document by such corporation.

(3.) Application of state laws,-Except as otherwise provided herein or in other laws of the United States, the laws of the states relating to the capacity of the parties to make, the execution, consideration, evidence, effect, and enforcement of, and limitations of actions upon, contracts made with such corporations shall be applied as in other cases.

\$90. Mortgages. (1.) Stockholders to authorize,-Mortgages, except,purchase money mortgages covering only the property purchased, upon the real estate or franchise of the corporation shall not be valid unless they are approved or authorized by the vote of 
a majority of the outstanding shares, and bonds having the right to vote.

(2.) Fictitions,-Mortgages given upon the corporate property to secure an amount greater than the consideration received by the corporation shall be invalid as against the creditors, the receiver, or a dissenting shareholder to the extent of such excess, and the person to whom such mortgage is given shall be liable to the corporation, the creditor, shareholder, or any bona fide purchaser of the bond, debenture or other negotiable instrument secured thereby, as provided in sections 47 and 48 .

(3.) Registration,- Every mortgage or charge created by such corporation for the purpose of securing any issue of bonds or debentures, or upon uncalled capital, or upon the personal property and chattels, or as a floating charge upon the property of the corporation, so far as creating a lien upon the property of the corporation, shall be void against the receiver, or any creditor thereof, unless such mortgage shall be filed within sixty days after its execution in the office of the Commissioner of Corporations, who shall keep aregister thereof, properly indexed, showing the date of filing; the date of execution; the date of the resolution of the shareholders authorizing the same; the number of shares voting therefor; a short description of the property mortgaged; the states in which located; the name of the mortgagee; in case the mortgage is to secure a series of bonds or obligations, it shall be sufficient, as to the amount, to state the total thereof, and as to the mortgagee, to state the name of the trustees, if any, for such holders; and if more than one issue is made of the same series, the date and amount of the new issue, with reference to the former, need only to be made.

(4.) Contract valid,-Failure to file and register such mortgage as provided herein shall not invalidate the contract or obligation to repay the money secured thereby; but registration as herein provided shall not in any way excuse compliance with or modify the effect of failure to comply with the state laws relating to filing and registration of liens upon property therein.

(5.) Certificate,-The said Commissioner shall give to such corporation a certificate of the registration of such mortgage, and the amount secured thereby, which shall be conclusive evidence of compliance herewith, and a cops of such certificate shall be endorsed upon every bond or debenture secured by such mortgage. 
When evidence is given to the satisfaction of the Commissioner that such moitgage or charge has been paid he shall enter on the register thereof a memorandum of satisfaction, and on request, furnish a certificate to that effect.

(6.) Fiees,-Fior such registration, certificates, or copies thereof such commissioner shall be entitled to 25 cents for each 100 words, but for registration or copy thereof not less than $\$ 1.00$, and for each certificate not less than 25 cents.

(7.) Inspection,-Such register of mortgages shall be a public record open to the inspection of any person desiring to see the same.

(8.) Corporation register, -The corporation itself shall keep a register of its mortgages as provided in section 128.

\$ 9l. Forfeiture of Shares. (1.) Sale, 一If the owner of any shares shall neglect to pay any sum due thereon for thirty days after the time appointed for payment, the treasurer, when ordered by the board of directors, shall sell at public auction such shares of the - delinquent owner, or such number of them as will pay all sums then due thereon, with interest and all necessary incidental charges, and shall transfer the shares sold to the purchaser, who shall be entitled to a certificate therefor.

(2.) Notice, - The treasurer shall give notice of the time and place appointed for the sale, and the sum due on each share, the number of the certificate, and the number of shares offered for sale, by advertising the same once a week for three successive weeks immediately before the date of sale, in some newspaper of general circulation published in the county where the registered office is located, and by mailing notice thereof, post paid, to the delinquent stockholder at his last known post office address, at least twenty days before the date of sale.

(3.) Proceeds, - If the proceeds of the sale of such shares are more than sufficient to pay the sums due thereon, with interest and expenses, the balance shall be held by the corporation for such stockholder, and paid to him or his representatives or assigns, at any time upon surrender to the corporation of his certificate of such shares. If the proceeds are not sufficient to pay the amount due with interest and charges, the stockholder shall remain liable to the corporation for the deficiency, to be collected by action therefor.

(4.) Purchase by corporation,-If no one offers enough to pay the sums due on such shares with interest and charges, the treas- 
urer may bid the shares in for, and they shall be declared forfeited to, the corporation; but the delinquent owner shall be liable to the corporation for such deficiency, and upon payment thereof within sixty days, or if the corporation recovers the same within such time, such stockholder, on surrender of the certificate shall be entitled to a new one stating that the sums due on such shares have been paid; otherwise the said shares and all that has before been paid upon them shall be deemed forfeited to the corporation, to be held by it as treasury stock and to be sold by it at such time as the corporation may deem expedient.

\section{Amendments.}

\$92. Before Subscription. Before the subscription of any part of the capital stock except that agreed to be taken by the incorporators, the Agreement of Association may be amended in any respect whatever consistent with the provisions of this Act, by entering into a new Agreement of Association, signed by all the original incorporators, and completing the organization thereunder as provided in sections 70 to 83.

\$93. After Subscription. After any part of the stock has been subscribed, or agreed to be taken by others than the original incorporators, and before organization, the Agreement of Association can be amended only in the particulars stated in sections 101 and 102 and by the vote required therein, in a meeting notified and conducted as provided in sections 70 to 73 in regard to the organization meeting; the notice shall state the purpose of the meeting and the nature of the proposed amendment; if the amendment is duly adopted the organization may be completed under such amended Agreement of Association.

$\$ 94$. After Organization. After organization of the corporation, the Agreement of Association, the By-Iaws, the Articles of Organization, or the Certificate of Incorporation may be amended in any of the particulars stated in sections 101 and 102 by the vote of the shareholders therein indicated, provided the board of directors shall pass.a resolution declaring such change is advisable, and shall call a meeting of the stockholders to take action thereon. The meeting shall be held upon such notice as the by-laws provide, but not to be less than three weeks, given personally or by mail, stating the purpose of the meeting and the nature of the proposed amendment. If the proposed amendment receive the proper majority vote, a certificate of that fact indorsed upon or annexed to a copy 
of such amendment, shall be signed by the president and secretary under the corporate seal, and such amendment and certificate, and, if the amendment requires a two-thirds vote, the written assent in person or by proxy of those who voted for the same, with the number of shares voted by each, shall' be submitted to the Commissioner of Corporations, and if certified by him to be according to law, shall be filed in the offlce of the Secretary of the Department of Commerce and $I_{\text {abor, }}$ and upon the payment of the fee required, the amendment shall be deemed to be made accordingly, provided the amendment made is such only as it would have been lawful to make in the original organization of such a corporation. Such amendments shall be filed, recorded, indexed, certified, printed, and distributed as provided in sections 77 to 79 and with the same effect, as in case of the Certificate of Incorporation, and the corporation shall cause copies of the same to be kept, filed, and recorded, and shall furnish the same, as provided in case of the Certificate of Incorporation.

\$ 95. Increase .or Decrease of Stock. (1.) Power.-The corporation may increase or decrease its capital stock or any class thereof, by the vote required by section 102, and by proceeding as set forth in section 94, relating to amendments.

(2.) Increase, - If the stock is increased the provisions of this Act relating to the subscription, issue payment, and liability of the holders, of the original stock shall apply.

(3.) Decrease, - If the stock is decreased, the amount of the reduced apital shall not be less than the amount of the debts and liabilities; and the owner of any. stock shall not be relieved from any liability existing prior to such reduction of the stock. The certificate signed by the president and secretary that the amendment reducing the capital stock has received the proper vote required to be made and filed, according to section 94 , shall also certify that the debts and liabilities do not exceed the amount of the reduced capital.

(4.) Redemption,-If any corporation has provided in its Agreement of Association for redeeming any class of its capital stock, the stock may be so reduced, provided the debts do not exceed the amount of unredeemed capital, after redemption, without amending the certificate of incorporation as above provided.

\section{Consolidation.}

$\S 96$. Power. Two or more corporations formed under this Act 
for the purpose of engaging in the same kinds of national commerce may merge or consolidate under the following conditions:-

(1.) Transportation, - Two or more transportation companies whose lines are connecting and continuous may merge or consolidate into a single corporation which may be either one of the merging or consolidating corporations, or a new corporation.

(3.) Transmission,-Two or more transmission companies whose lines are connecting and continuous may merge or consolidate into a single corporation which may be either one of the merging or consolidating corporations, or a new corporation.

(3.) Trading, - Two or more trading corporations engaged in the same kind of national commerce may merge or consolidate into :a single corporation which may be either of the merging or consolidating corporations, or a new one; but if more than one of such corporations are engaged in, or have power to engage in, the business of producing, farming, mining, or manufacturing, such corporations shall not consolidate except as may be permitted by the law of the state or states where said business is carried on.

(4.) Limits, - A transportation corporation shall not consolidate with a trading company; but a transmission corporation may consolidate with either a transportation or a trading corporation, in which case the name must indicate that the new corporation is engaged in both kinds of national commerce. Corporations formed under this Act shall not consolidate with companies not formed under this Act.

\$ 97. Procedure. (1.) Agreement,-The directors of the several corporations proposing to merge or consolidate shall first enter into a joint agreement in the names and underthe seals of the respective corporations, fixing the terms and conditions of such proposed merger or consolidation, and the mode of carrying the same into effect, and, in regard to the consolidated corporation, stating the name; the location of the registered office; the name of the registered agent; the number, names, and residence of the directors and officers, who shall hold their offices until their successors are chosen and qualified; the amount of capital stock; the number of shares; the par value of shares; the classes of stock, if any, with a full description of the privileges thereof; the manner of converting the capital stock of the merging or consolidating corporations into the stocks or obligations of the consolidated corporation; the disposition to be made of any stocks or obligations of the new corporation not 
to be issued in exchange for those of the consolidated corporations; the by-laws proposed to be adopted; and such other matters as may be deemed necessary to perfect the merger or consolidation.

(2.) Provisions of agreement, - Such agreement of consolidation may provide for the issue of stock, bonds, debentures or other obligations, negotiable or otherwise, sufficient to make all payments such consolidated corporation will be required to make, or to discharge all obligations it will be required to assume, in order to effect such consolidation; and may provide for securing the payment of such bonds, debentures or obligations, by mortgage upon the property of the corporations to be consolidated, but such mortgage shall be subject to the full payment, to the extent of the propexty mortgaged, of all claims against the former corporation whose property is so mortgaged.

Provision may be made for issuing stock of the consolidated. corporation to the stockholders of the former corporations in. exchange for their shares, or for the property of such former corporations or for money paid or to be paid in; but all the provisions. of this Act relating to the issue, or payment, of stock, the form and. contents of the certificates of shares, and the liability of shareholders, in the case of a single corporation, shall apply to such consolidated corporation.

(3.) Adoption and filing of agreement, -The proposed agreementof consolidation shall be submitted to a stockholders' meeting.of each of said merging or consolidating corporations, separately called and conducted as is provided in section 94 in regard to amendments after organization; if such agreement receives the requisite number of votes, it shall be certified by the president and. secretary of each of the consolidating corporations under their corporate seals, and such agreement, and certificate, with the written. assent of those who voted for the same, with the number of shares. voted by each, shall be submitted to the Commissioner of Corporations, and if approved, shall, upon payment of the proper fees, $(\$ 80)$ be filed, recorded, indexed, certified, printed and distributed as provided in sections 77 to 79, and with the same effect as in case. of the Certificate of Incorporation, and Amendments.

$\S$ 98. Effect. Such former corporations shall, after consolidation, be considered in law as one consolidated corporation by the name. assumed, clothed with all the rights and powers given, and subject to all the duties, and liabilities contained herein; but in case of: 
amendments made to the laws of the United States, such corporation shall be considered as coming into being at the time of filing the Agreement of Consolidation with the Secretary of the Department of Commerce and Labor, and shall then have the powers given by, and be subject to, the laws as they then exist, or shall thereafter be modified; otherwise such consolidated corporation shall possess all the rights, privileges, powers, and franchises, public and private, and be subject to all the restrictions, disabilities and duties of such consolidating corporations.

All the rights, privileges, powers, franchises, and property, real, personal, or mixed, including all credits, accounts, and rights of action of whatsoever kind, belonging to each of the consolidating corporations, and the title thereto, shall be vested in, and may be enforced by, such consolidated corporation, without any further instrument of transfer or conveyance; and likewise all rights of creditors against, and all liens upon any of the property of, either of the former corporations shall be preserved unimpaired, and all the debts, liabilities, duties, and obligations of any kind whatsoever of either of the former corporations shall thenceforth attach to said consolidated corporation, and may be enforced against it to the same extent as if said debts, liabilities and duties had been incurred or contracted by it; but the former corporations may be considered to be in existence in order to enforce the liabilities thereof existing at the time of the consolidation, in the same manner and with the same effect as if the consolidation had not taken place.

\section{Selling Out.}

$\$$ 99. Power and Procedure. Such corporation may sell all its corporate property, rights and franchises to any other corporation with which it might consolidate, organized, or to be organized, under the provisions of this Act, provided the directors first enter into a provisional contract therefor, and pass a resolution declaring it advisable to do so, and call a meeting of the stockholders to take action thereon, in the same manner as is provided in the case of amendments, and if agreed to by the requisite majority, the action shall be certified as in the case of amendments made after organization (\$ 94). Upon the filing of such certificate with, and the payment of the requisite fee to $(\S 80)$, the Secretary of the Department of Commerce and Iabor; the said corporation shall be considered as going out of existence, except for the purpose of enforc- 
ing existing claims against it, and the rights and pripileges thereof shall be vested in, and the duties and liabilities shall be, assumed by the purchasing corporation, with the same effect and subject to the same limitations as is provided in section 98 in regard to consolidation.

VI. MLANAGENIENT.

1. Shareholders.

$\S 100$. Elect Directors. The-power to elect directors shall be vested in the shareholders, or in those entitled to vote for such directors, and shall be exercised in the manner provided in sections 111 to 113.

\$ 101. Business Matters. The power to make or modify by-laws; to change the par value of shares; to change the corporate name; to change the location of the registered office; to control the issue of stock; to mortgage the property, or franchises and to remove officers, shall be vested in the shareholders, or in those having voting power, in a corporate meeting duly assembled by a majority vote of all the outstanding shares or of those entitled to vote; or if there are more than one class of shares, by a majority vote of all the outstanding shares of each class.

$\$$ I02. Material Amendments. The power to increase or decrease the capital stock; to classify the shares; to change the voting power of any shares; to issue bonds with voting powers; to change the nature of the business; to merge or consolidate with any other corporation; to accept or make any other material amendment, change, or alteration in the constitution of the corporation; to sell all the property or franchise; to surrender the corporate franchise; or to dissolve the corporation, shall be vested in the shareholders in corporate meeting duly assembled, by the afirmative vote of twothirds of all the outstanding shares, or of those entitled to vote thereon, or if there are more than one class of shares, by the affirmative vote of two-thirds of all the outstanding shares of each class.

$\S 103$. Other Matters. Such other powers as are conferred upon the shareholders by law, or. by the Agreement of Association, the by-laws, or the Articles of Organization, unless otherwise provided, shall be vested in and exercised by the shareholders in meeting duly assembled, by the majority vote of the quorum.

\section{Shareholders' Meetings.}

$\$ 104$. Necessity. Except as otherwise provided herein, share- 
holders shall act only in shareholders' meeting; but such regular and special meetings of the stockholders may be held as may be provided in the by-laws, or as the business may require.

$\$ 105$. Annual. An annual meeting of the stockholders shall be held within sixty days after the end of the fiscal year of the corporation, for the purpose of electing directors and officers, hearing and considering the annual report and such other matters as may be properly brought before it.

$\S 106$. Place. The time and place of holding, and the manner of conducting such meetings shall be fixed by the by-laws, but all stockholders' meetings shall be held within territory subject to the United States, and unless otherwise provided, shall be at the registered office of the corporation.

$\S 107$. Call. The secretary of the corporation shall call all regular meetings of the stockholders at the time and place fixed by law, or by the by-laws. A written or printed notice of every stockholders' meeting, whether regular or special, stating definitely the day, hour, purpose, and place thereof, shall be given by the secretary at least ten days, or in case any propositions to amend the Agreement of Association, the by-laws, Articles of Organization, Certificate of Incorporation, or to consolidate, to sell out, or to dissolve the corporation, are to be acted upon, the notice shall state the nature of the proposed change, and shall be given at least three weeks, before the meeting to each stockholder by leaving a copy of such notice with him, or at his residence, or usual place of business, or by mailing it, postage prepaid, addressed to him at his last known address. But no notice shall be required if every stockholder is present in person or by his duly appointed attorney, and shall in writing filed with the records of the meeting waive such notice.

. \$108. Special. Special meetings of the stocikholders may be called by a majority of the directors, or by the President or Secretary upon the written request of three or more shareholders, who are entitled to vote, and who hold at least one-fiftieth part in interest of the capital stock, by giving such notice as provided above in section 107.

$\$ 109$. Failure to Call. If for any cause any offcer whose duty it is to call a meeting is unable, refuses, or neglects to do so at the proper time, or upon proper application, any justice of the peace, or any judge of a state or federal court, may upon written application of three or more stockholders, issue his warrant to any one of 
them, directing him to call a meeting by giving the notice required by this Act, and authorize him to "preside at such meeting, if no officer legally authorized to preside is present, or, if present, refuses to preside.

§ II0. Quorum. Unless the charter or by-laws otherwise provide, a majority of all the.shares issued and outstanding and entitled to vote shall constitute a quorum for the transaction of business; but elections of directors and officers, and amendments, consolidations, selling out, and voluntary dissolutions, shall require the votes indicated in sections 112, 101, 102.

\section{Elections.}

\$ III. OF Directors. (1.) Time, place, manner,-Elections of directors, and of such officers as are required to be elected by shareholders, shall take place at the annual meeting; shall be by ballot; and shall be in charge of two inspectors to be appointed by resolution of the directors or of the shareholders; and the inspectors shall take, and file with the corporate records, an oath faithfully to discharge their duties as such inspectors.

(2.) List of shareholders, -The directors shall cause the reg"istered agent, or other transfer agent designated by them to make, at least ten days before every election after the first, $\dot{a}$ full, true and complete list, arranged in alphabetical order, of all the shareholders and persons entitled to vote at such elections, with the post office address of each, the number of shares of each class of stock, or bonds with voting power, held by each upon which he is entitled to vote. This list shall be kept at the registered office, and during business hours shall be open to the inspection of any shareholder, and within three days after request therefor, and the payment of the cost of copying at not over ten cents per one hundred words, shall furnish any stockholder with a copy thereof.

Such list and the stock and transfer books and the proxies shall be produced at the time and place of and during every election, and shall be open to the inspection of any shareholder.

(3.) Voteris,-No shares which have been issued, (except in the case of the organization meeting), or transferred upon the corporate books, within twenty days immediately preceding such election shall be voted on; otherwise the provisions of section 154, as to voting by proxies, fiduciaries, or upon shares pledged or held 
by the corporation, or by other companies in violation of this Act, or by delinquent holders, shall apply. If theright to vote upon any share be questioned, the inspectors shall determine the same by reference to the stock or transfer books of the corporation, and by an inspection of the proxies filed.

\$ 112. Quorum. At least a majority of all the outstanding shares, and bonds with voting power, entitled to vote, or if different classes of shares are entitled to elect any particular class of directors, a majority of all the outstanding shares of each class entitled to vote, shall attend in person, or by proxy, in order to constitute a quorum for conducting an election; and the persons to the number required to be elected, receiving the highest number of votes, and of the ' class authorized to vote therefor, shall be declared to be elected directors; but if the Agreement of Association so provides, the shareholders, or any class thereof may cumulate their votes in the manner provided.

\$113. Return. The inspectors shall make return of the election in writing, and shall accompany the same with the list of shareholders indicating thereon what shares were not represented, what were represented in person, and what by proxy, and who was the proxy, and shall verify such return and list under oath, and the same shall be filed with the records of the corporation.

\$ 114. Other 0fficers. The election of the auditor, or auditors, and such other officers as are to be elected by the shareholders shall take place after the directors are chosen, and shall be conducted in the same manner.

$\$ 115$. Failure to Elect. If for any reason directors or officers are not elected at the regular annual meeting, a special meeting shall be called for the purpose within thirty days, at which directors and officers shall be elected in all respects as at the annual meeting. Failure to elect directors or officers shall not affect the corporate existence, but the former incumbents shall hold their offices until their successors are elected and qualified. Vacancies are to be filled as provided in section 118.

\section{Directors.}

$\S 116$. Powers. The management of the ordinary business and affairs of the corporation, and such as is not otherwise conferred upon the shareholders, shall be vested in the board of directors, in meeting duly assembled, and their action may be then determined by a majority vote of the quorum. 
\$ 117. Meetings. (1.) Regular, -The time and place of the regular meetings of the board shall be provided for in the by-laws, but unless another place shall be so designated, such meetings shall be held at the registered office of the corporation; but any meeting of the board, by unanimous consent, may be held anywhere.

(2.) Special,-Special meetings may be held at the registered office of the corporation, on the written request of the president, or of any three members of the board.

(3.) Call,-The secretary shall give to each member notice of all special meetings, either personally by leaving with him, or at . his usual place of business, or by mailing to him postage prepaid at his last known address, in time to reach him at least twenty-four hours before the time of meeting, and in time for him to attend, a written or printed notice of the time and place of such meeting, and the purpose thereof; provided, that if all members of the board attend any meeting no notice thereof shall be necessary to the validity of the action taken.

(4.) Quorum,-A majority of all the directors shall constitute a quorum.

(5.) Voting, - Eiach director shall have one vote, which he shall cast in person.

(6.) Business, - At the first meeting of the board of directors after the annual election, they shall proceed to elect, by ballot, such officers as the charter or by-laws authorize them to choose. A majority of the votes cast shall be necessary to elect.

(7.) Rules, -The directors may adopt such rules and regulations for conducting and facilitating their business as are not inconsistent with the charter or by-laws of the corporation.

\$ Il8. Vacancies in Office. Any vacancy accurring in the board of directors or in the office of president, vice-president, secretary, or treasurer, by death, resignation, removal, or otherwise, shall be filled in the manner prescribed in the by-laws. In the absence of any provision therein, such vacancies, as. well as others, except as hereinafter provided, shall be filled until the next election, by the board of directors; in case of a vacancy in the office of auditor, a sbareholders' meeting shall be called for the purpose of electing a new auditor, and when the number of directors is increased between the annual meetings, the new places shall not be considered vacancies within the meaning of this section, but shall be filled by an election by shareholders called for that purpose. 


\section{Officers.}

$\$ 119$. In General. The powers, duties, and functions of the officers shall be such as may be, or is, conferred upon, or assigned to, them by law, or by the by-laws, or by the shareholders, or directors, or such as are usually exercised, performed and discharged by such officers, unless otherwise provided or directed.

\$120. President. (1.) Preside,-The president shall preside at the meetings of the stockholders, and of the directors; he shall sign the minutes of meetings over which he may have presided; he shall sign the certificate of stock, and such other notices, instruments, and documents as may be required by thecharter, by-laws, or resolution of the board.

(2.) Manage,-Unless some other officer is designated as such, he shall be presumed to be the general manager, and may exercise the powers usually conferred upon such an officer, in carrying on the current business operations of such corporation.

(3.) Report,-He shall submit at the annual meeting a complete report of the operations and financial affairs of the corporation for the preceding fiscal year, as hereinafter provided.

(4.) Other,-He shall perform such other duties as usually pertain to his office, or such as may be delegated to him.

\$ I2I. Vice-President. In the absence or inability of the president, the vice-president shall have the powers, and shall perform the duties, of the president.

$\S$ 122. Secretary. The secretary shall keep full and correct minutes of the meetings of the stockholders and of the directors; shall issue calls for meetings; shall notify officers and directors of their election; shall keep the corporate seal and affix the same, attested by his signature, to such instruments as are required or authorized to be under seal; and shall perform such other duties as are usually incident to such an office, or as may be conferred upon him by the by-laws or otherwise.

§ 123. Registered Agent. The Registered Agent shall keep his office at the registered office of the corporation, and shall keep there the stock and transfer books of the corporation, written up to date, and such other documents as are herein designated, open to the inspection of all bona fide stockholders, and ready to be used for the transfer of stock. Notices given or sent to him at the registered office, or summons or subpcenas served upon him at such office in 
the manner prescribed in section 88 (2), shall be deemed to be properiy given to or served on such corporation.

\$ 124. Treasurer. The treasurer shall have the custody of, and be responsible for all moneys and securities of the corporation, and shall keep full and accurate records and accounts of the same, which shall be open at all times during business hours to the inspection of any director of the corporation. He shall have power to endorse for collection or deposit all bills, notes, checks, and other negotiable instruments; he shall pay out money upon direction of the proper authority; and shall make such reports and statements from time to time, as may be required by the directors or otherwise.

\$ 125. Auditors. The Auditors shall ascertain and report to the corporation annually whether, in their judgment, the corporate books have been properiy kept and show correctly the condition of the business affairs, and transactions of the corporation; whether every shareholder's balance sheet, as provided in section 132, laid before the members of the corporation during their term of office, presents a correct view of the state of the corporation's business and affairs; or if they think otherwise, they shall report in full wherein they disapprove, or find the books or balance sheets, deficient, and the details of their disapproval thereof shall be indorsed on such balance sheets, or annexed thereto, and filed therewith; they shall also report all material information which they may have obtained concerning the books, accounts, securities, vouchers, writings, and documents examined by them, not shown by such balance sheets; their report shall be made in writing and certified under oath to be correct to the best of their knowledge and belief, and shall be submitted along with the shareholders' balance sheets, and both shall be read at the annual shareholders' meeting.

The auditors shall, before making such report, require a copy of the private balance sheet showing in detail the items upon which the shareholders' balance sheet is founded, to be furnished them, and shall have the power to require the directors and officers, or any of them, to supply in writing, signed by the party giving it, any further details, information, or explanation, possessed by them or him, affecting either of the balance sheets or any item therein; and they shall have, at all times, access to and full power and authority to inspect the books, accounts, papers and vouchers, or any of them, of such corporation, in order to verify the accounts and make the required certificate, and their certificate shall show. whether or not all their requisitions have been complied with. 


\section{DUTIES AND ITABITITIES.}

§ 126. As to Name. Every such corporation shall have its corporate name painted, or affixed, and shall keep it so painted or affixed, in English letters easily legible, in a conspicuous position on the outside of every office or place in which the business of the corporation is regularly carried on; it shall likewise have its name engraved in legible English characters on its corporate seal, and shall have it likewise printed or mentioned in all notices, advertisements, reports, and other official publications, and on all bills, contracts, invoices, receipts, and letters signed by or on behalf of such corpoiation.

§ 127. As to Registered Office. The registered office shall be kept open regularly during ordinary business hours, and the registered agent shall be there to perform the duties required. The location of the registered office, and the name of the registered agent, shall be printed or stated upon all letter heads used by the corporation, and upon every report or statement required by this act to be made to any public officer, or published, or filed or recorded by such corporation, and no such document or statement shall be received, or filed by any officer of the United States, unless this provision is complied with.

\$ 128. Documents in Registered Office. (1.) Organization papers, - Copies of all organization papers, including the Agreement of Association, By-Iaws, Articles of Organization, and Certificate of Incorporation, with all amendments to any of them, shall be kept in the registered office, open to the inspection of all shareholders or creditors, at any time during business hours.

(2.) Records of meetings, - Such corporation shall keep at all times, at its registered office, full and true records of all the proceedings of the shareholders' and directors' meetings, open to inspection of directors and shareholders.

(3.) Transfer books, -The stock and transfer books of the corporation shall be kept in the registered office in charge of the registered agent, who shall keep them written, up to date, and they shall be open to the inspection of all bona fide shareholders, during business hours, and shall be ready for the transfer of shares.

(4.) Lists of shareholders, officers, etc., -Every such corporation shall cause to be kept in the registered office a list in which shall be entered the names and addresses of the members, with the number of shares held by each, distinguishing each certificate by its 
number, showing the amounts paid or considered as paid on such shares, and the date at which any person ceased to be a member; there shall likewise be kept in 'such office a list of the names and addresses of the directors and- officers of the corporation; a list of the dates of the certificate of incorporation, and all amendments theteto shall likewise be kept in such office; and the foregoing lists shall be subject to the inspection of all the shareholders and creditors of the corporation, during the regular business hours of each day in which business may be legally transacted.

(5.) Balance sheets,-Copies of all stockholders' balarice sheets, and of all annual reports made by such corporation to any public officer, as hereinafter required, shall likewise bekept in such office, and open to inspection by shareholders during office hours.

(6.) Mortgages, - Evivery corporation organized hereunder shall cause a copy of every instrument creating any mortgage or charge requiring registration under this Act, or otherwise, to be kept at the registered office, properly filed and indexed, and open to theinspection of the shareholders and creditors; provided that in case of a series of uniform bonds or debentures, a single copy of the same, with the total amount issued, and the names and addresses of all the parties to whom the same were issued, and the names of the transferees thereof shall be sufficient.

\$ I29. Accounts to be Kept. Eivery such corporation shall cause to be kept proper books of account, in which shall be kept full, true, and complete accounts of the affairs and transactions of the corporation.

\$ 130. Fiscal Year. The fiscal year of such corporation shall be made to end on the thirtieth day of June of each year, and the first report of any corporation commencing business more than three months prior to June thirtieth, shall be made for the part of the year ending with that date; if commencing business less than three months prior to any thirtieth day of June, the first report may be made for such part of the year and the following year together.

\$ 131. Private Balance Sheet. Such corporation shall within sixty days after the end of the fiscal year cause the proper accounting officers to balance its accounts and to make out a private balance sheet and report, which shall show in detail the items making up the capital stock, authorized, issued, and paid up; the assets; the property of all kinds; the debts and liabilities of all kinds; the gross and net earnings; the income and profits; the operating 
expenses, and expenditures of all kinds; and a summary of business done; the number of shareholders of each class; the officers and salaries paid to each; the number, or average number, of employees, with the total wages paid, for the preceding fiscal year; indicating where, in the books of account, and statements may be inspected or verified. Such balance sheet shall be signed by the president and at least three of the directors, and shall be open to the inspection of the auditors, but shall not be issued to the members of the corporation. The auditors may call for, and require to be furnished in writing any further details or information they deem necessary, and shall certify on such balance sheet whether or not the same was furnished as requested. The private balance sheet together with such further details and information shall be.kept by the corporation as a part of the records thereof.

\$ 132. Shareholders' Balance Sheet. (1.) Contents,-Such corporation shall likewise cause to be made, within fifteen days after the private balance sheet is completed, a Shareholders' Balance Sheet, to be prepared by the proper accounting officers, from the items given in the private balance sheet. Such shareholders' balance sheet may be such as may be prescribed by the by-laws, or by resolution of the shareholders, but in every case shall show, as to

I. Capital and Liabilities: (1.) The amount of capital stock issued, the amount paid up thereon, indicating the amount paid up in money, in property, in services, or otherwise, stating the nature of the consideration received if other than money; the arrears of calls due, the dates thereof, the names of those in defatult, and the particulars as to any forfeited shares.

(2.) The debts and liabilities of the corporation, indicating the amount of mortgages, debentures, and the floating debts, or current liabilities outstanding, stating the amounts for which notes or acceptances have been given; the sums due for supplies; for material; for labor; for taxes; for salaries; for interest on loans; for legal expenses; for unclaimed dividends; and for all other liquidated claims or obligations.

(3.) The amount of reserve fund to meet contingencies if any.

(4.) The balance, or the actual amount of the years' earnings, and surplus, available for the payment of dividends or to be otherwise disposed of, and the nature and mode in which it is, or is to be used or invested, with the rate of interest, if any, received or to be received. 
(5.) Claims for which the corporation is or may be contingently liable, and also such claims, made against the corporation, with the nature thereof, as are not acknowledged as debts, or valid claims.

II. Property and Assets: (1.) The tangible property, distinguishing the freehold lands and buildings; leasehold lands and buildings; office furniture, fixtures and supplies; machinery and equipment; merchandise, indicating the products, material, and stock in processs, on hand.

(2.) The intangible property, indicating separately, franchises, patent rights, trade marks, good will, etc.

(3.) Debts due the corporation, including and separately indicating billsreceivable, accounts receivable, agents' balances, etc., showing those considered good and for which the corporation holds securities of any kind, naming them;' those considered good for which no securities are held; those considered bad or doubtful. Any debt due the corporation from any director or officer shall be separately stated.

(4.) Investments and securities of other institutions held, stating their face 'value, and their estimated actual value, indicating where and how invested, and the rate of interest .or income therefrom.

(5.) Cash, indicating where deposited.

(6.) All other assets, or claims, liquidated and unliquidated, indicating separately their nature, character and amounts.

(7.) There shall also be stated as to all the assets except cash, whether they are taken at cost price or by valuation, or on what other basis they are reckoned, and whether any, and if so what, amount or percentage has been written off, or what other provision has been made, for depreciation.

(8.) The amount by which the'gross value of the assets of the corporation has been increased since the last balance sheet. due to any increase in the valuation of any property of the corporation.

(9.) The amount of property for which shares were issued which has been sold since the last balance sheet, with a full aisclosure of the consideration received therefor in detail, the parties to the contract, and the real parties in interest.

III. Income, showing separately the amounts (1.) From business done. (2.) From investments. (3.) From rentals. And (4.) from all other sources. 
IV. Expenditures, showing (1.) General expenses, indicating cost of administration, superintendence, salaries, and office expenses.

(2.) Maintenance, showing separately the cost of ordinary repairs, and of extraordinary replacements, and the cost of the material, supplies, labor, and transportation therefor.

(3.) Conducting or carrying on the business, showing separately cost of material, supplies, labor and transportation therefor. etc.

(4.) Fixed charges, showing taxes, insurance, interest, rentals,

(5.) Any other ordinary expenses.

(6.) Dividends declared and paid.

(7.) Payments into sinking or other reserve funds.

(8.) Net income, or undivided profits or surplus.

$\checkmark$. The total number of shareholders of each class, at the end of the fiscal year.

VI. A summary of the amount of business done by the corporation.

VII. The average number of employees, and the total amount of the pay roll for the year, indicating separately the amounts paid as salaries to the general officers, and the salaries paid to all other agents and the number thereof; the total amount of wages paid and the average number of workmen employed.

(2.) Copies to be furnished, - Such balance sheet shall, at least fifteen days before the annual meeting, be examined by two or more directors who shall certify thereon on behalf of the board that the same, in their opinion, is drawn up so as to exhibit and does exhibit, a correct statement of the corporation's affairs at the end of the fiscal year. Such balance sheet shall then be duly audited, and it with the auditors' report thereon, shall be filed in the registered office at least ten days before the, annual meeting and shall be open to the inspection of the members of the corporation. A copy of such balance sheet and the auditors' report shall be mailed, by the secretary or registered agent, to the last known address, postàge prepaid, to each director, at least ten days, and to each shareholder, at least seven days, before the annual meeting.

(3.) To be read at annual meeting,-Such balance sheet with the directors' certificate and the auditors' report shall be read at the annual meeting of the shareholders, and unless any director shall before or at such meeting make statements to the contrary, he 
shall be held to have signed and certified to the correctness of such balance sheet.

$\$ 132 a$. Liabilites in General. (1.) Contracts,-Such corporation shall be liable upon its contracts entered into according to the provisions of this Act by its duly authorized agent, as in the case of natural person.

(2.) Torts,-Such corporation shall also be liable in the same way and to the same extent as natural persons, for the torts of its agents and servants done in the course of their employment for or on behalf of such corporation; the malicious and wilful acts of the agent in performing his functions as such agent of the corporation shall be imputed to such corporation, and be sufficient to make it liable in exemplary damages; those officers and agents to whom are entrusted the duties of providing safe places in which to work, or safe materials, machinery, and appliances to work with, or to inspect the same, or to hire competent servants, shall not be considered fellow servants with those who rely upon the faithful performance of such duties, so as to relieve such corporation from damages due to the negligent performance of such duties. Such corporation shall be deemed guilty of negligence for failure to comply with the provisions of section 142, and be subject to the employers liability provided in section 146.

(3.) Crimes, - Such corporation shall be liable to the penalties provided in this Act for violatious of its provisions; and may be indicted and fined for any public nuisance, or any act of malfeasance, or misfeasance amounting to a misdemeanor, or violating any statute or common law duty. and which a corporation from its nature is able to commit, punished by a fine under the laws of the United States.

(4.) Execution,-The property of any such corporation may be taken in execution and sold to satisfy any judgment or penalty against such corporation, except such property of a transportation or transmission corporation, as is essential to the performance of the public duties of such corporation, but any debt due such corporation may be garnished, or its earnings sequestered until such debt is discharged; if no property can be found a receiver may be appointed to wind up such corporation as provided in section 186.

VIII. CONTROL.

1. Legislative, Extraordinary.

$\S$ 133. In General. Such corporation shall be deemed to hold its 
franchises, powers, and privileges from the United States, and shall be subject to the control and regulation thereof, but shall not be subject to the control and regulation of any other state except as herein provided.

$\S 134$. Repeal. Any corporation organized under this Act shall be subject to dissolution, or may have its charter altered, amended, or modified by Act of Congress at its pleasure, and this Act and all or any of its provisions shall be subject to alteration, amendment, modification, or repeal by the Congress of the United States, at its discretion.

$\S$ 135. Purchase, Eminent Domain. The United States may at any time after ten years after the passage of this Act, for postal, military or other purposes, or in order to regulate national commerce, purchase the property, effects and rights of any or all transportation or transmission corporations organized under this Act at an appraised value to be ascertained by five disinterested persons, two of whom shall be selected by the President of the United States, and two by the corporation interested, and one by the four so selected. It shall be the duty of the Secretary of the Department of Commerce and I abor on or before the first day of November, 1923, and on or before the first day of November every twenty years thereafter to submit to the President a full report upon the desirability of a purchase by the United States of the property, effects, and rights of any one or more such corporations, and the President shall submit the same with his approval or disapproval to the Congress at its next session; and if the Secretary and President favor the acquisition of the property of any such corporation, the opinion of the qualified voters of the country, upon the desirability of the purchase shall be taken by submitting the question at the next presidential election to the vote of the people, as a basis for such further action as Congress shall desire to take. The foregoing provisions, however, shall not in any way affect the power of Congress to take action on the same either with or without such proceedings, or to provide for the acquisition of the property of any such corporation under the power of eminent domain.

\section{Police Control.}

§ 136. In General. Such corporation shall be subject to such regulations and control by Congress as the public safety, health, morals, convenience, or protection may require, and as Congress may from time to time determine. Such operations of such corporations as 
may be carried on. wholly within a state shall be subject to the police control thereof, so far as the public interest may require, and so far as the same does not interfere directly with the carrying on of the national commerce of such corporation, or which is not inconsistent with the provisions of this Act, or with the laws of the United States.

§ 137. Transportation Corporations. (1.) Subject to commerce act,. -All transportation and transmission corporations organized ander this Act shall be subject to the provisions of the Act to Regulate Commerce, of Fiebruary 4, 1887, 24 stat. 379, and the amendments. thereto.

(2.) Fiscalyear, uniform accounts, - And in addition thereto the fiscal year of such corporations as aresubject to such Act to Regulate Commerce shall be made to end June thirtieth in each year, and the report of such corporations required by such Act shall be filed on or before September 15th following; and the InterstateCommerce Commission is hereby given authority to prescribe a uniform system of accounts for such corporations, and require conformity thereto, and require such report to be certified to under oath by the President and chief accounting officer of such corporations. A monthly report of the earnings from operation, the operating expenses, and net earnings, shall be filed with such commission within sixty days from the close of each month.

(3.) Classification of freight,-Such commission shall, unlessthe common carriers to which the Act to Regulate Commerce applies, within six months after the passage of this Act, shall do so, adopt a uniform classification of freight to be operative throughout the United States in the carrying on of national commerce, and to. which all such carriers shall conform.

(4.) Schedules of rates, - Such commission shall determine and prescribe, and may amend, the form, contents, and arrangement of the schedules of rates and joint tariffs required by said Act to bepublished and filed, and such carriers shall conform to such forms; such rate sheets, tariffs, and all reports required herein or by such Act to be filed with such commission shall be competent testimony and prima facie evidence of what they purport to be in all proceedings before such commission or in the courts.

\$ 138. Interstate Commerce Commission to Fix Reasonable Rates. Such commission shall have power to hear and determine after dueand full investigation and inquiry, upon notice to, and full oppor- 
tunity to be heard by, any carrier, any complaint against such carrier, alleging that the rates, fares, or charges thereof are in any respect excessive or unreasonable, or that such rates, fares, charges, facilities or practices result in unjust discrimination as between individuals, localities, or articles of traffic, or are otherwise in contravention of any of the provisions of the Act; and shall make full report separately of the facts found, and the rules of law they deem applicable, and shall thereupon issue an order requiring any such rates, fares, charges, facilities, or practices, to be changed, modified, or corrected, and shall prescribe in detail what shall be considered lawful in respect thereto, under the conditions found to exist; and the procedure in the courts for enforcing such orders of the commission shall be confined to the record made before such commission, and the orders of such commission shall be enforced unless there shall be material error therein plainly prejudicial to the defeated party; in case of newly discovered evidence, or any alleged change of conditions that might justify a modification of such orders, said commission, : upon application supported by affidavits of the party applying, stating the nature of the evidence or change, may grant a rehearing and may modify such orders in such way as justice may require.

\$ 139. Rebates Forbidden. No transportation or transmission corporation or carrier organized under this Act, or subject to the Act to Regulate Commerce, nor any lessee, trustee, receiver, agent, or representative thereof, shall offer, grant, give, solicit, accept, or receive, any rebate, concession, facilities, or services in respect to the national commerce carried on by it, or any part thereof whereby the same shall, by any means whatever, be done at a less rate than that named in the tariffs published and filed by such corporation or carrier as required by' this Act, or the Act to Regulate Commerce. Any such corporation or carrier violating this provision shall be deemed to.have violated its charter, and if incorporated under this Act may be dissolved as provided in section 149 at the suit of the Attorney-General; and such corporation or carrier, and each person or party thereto representing such corporation or carrier, shall be guilty of a misdemeanor, and upon conviction thereof, shall be subject to a fine of not less than one thousand dollars for each offense.

$\S$ 140. Predatory Competition Forbidden. No company, whether formed under this Act or not, engaged in the production, 
manufacture, or sale of any article of commerce violating the preceding section, or attempting to monopolize or control the production, manufacture, or sale thereof, in any particular locality, by discrimination in prices, or by giving special privileges or rebates or otherwise, in order to destroy competition therein, in such locality, shall use, either directly, or indirectly, any of the facilities or iustrumentalities of national commerce, or in any way engage in such commerce, for the purpose of aiding or facilitating, either directly, or indirectly, such production, manufacture, or sale, with such intent; nor shall any other person or company use any of the facilities or instrumentalities of national commerce, or in any way engage in such commerce, in buying, selling, or disposing of any such article of commerce, for the purpose of enabling such first-mentioned company to engage, or to continue to engage, in such production, manufacture, sale, or control, with such intent. Every company or person, violating this section, shall be punished, on conviction, by a fine of not less than five hundred nor more than five thousand dollars.

\$141. Penalty. Any transportation corporation, or carrier engaged in national commerce, subject to this Act, or the Act to Regulate Commerce, or the lessee, trustee,receiver, or representative thereof, who shall knowingly transport, or aid in transporting, any property produced, manufactured, or sold in violation of section 140 of this act, or in violation of the Anti-trust Act of July 2, 1890, in national commerce, shall, if organized under this Act, be deemed to have violated its charter, and may be dissolved therefor as provided in section 149, and whether organized under this Act or not shall be subject to a penalty of not less than one thousand dollars for each offense.

§ 14la. Damages. Any person or corporation injured in business or property by any other person or corporation by reason of anything forbidden or declared unlawful by sections $138,139,140$ and 141 herein may sue in any circuit court of the United States where the defendants reside or are found, and shall recover threefold damages, the costs, and a reasonable attorney's fee.

§ 142. Safety of Employees. (1.) Transportation corporation,-Every transportation corporation organized under this Act shall be subject to the provisions of the safety appliances Act of March 2, 1893, as amended April 1, 1896, and March 2, 1903, and of the Act of March 3, 1901, requiring common carriers to report accidents to the Interstate Commerce Commission. 
(2.) Trading corporations,-Every trading corporation formed under this Act, and engaging in other lines of business than national commerce, shall, except so far as is inconsistent with this Act, be subject to the state regulations relating to hours of labor, safety appliances, inspection, sanitary conditions, and the employment of women and children, in the state where such other business is located or carried on.

(3.) Dangerous machinery,-And in any event any corporation formed under this Act shall, where any of its machinery and appliances, or any of the connections thereof, are so arranged and placed as to be dangerous to its employees while engaged in their ordinary duties, provide safe and secure guards therefor, if possible, and if not, then cause notices of the danger to be conspicuously posted near the same; and no minor or female shall be permitted to clean any of the same while in motion, and children under fourteen years of age shall not be permitted to operate or assist in operating dangerous machinery of any kind.

(4.) Dangerous premises, - Such corporations shall cause all openings, hatchways, elevators, well holes, upon each floor of any building to be protected br good and sufficient trap-doors, selfclosing hatches, or strong and sufficient guard rails at least three feet high, and all due vigilance shall be used to keep the same closed when not in actual use. All stairways shall be protected by a substantial hand rail, and shall be properly lighted and screened at sides and bottom; and the doors of all factories, so far as possible, shall open outward, and not be locked during working hours, and such factories shall be supplied with proper and sufficient fireescapes.

(5.) Female employees, - Whenever females are employed by such corporation, where unclean work of any kind has to be performed, suitable places shall be provided for such females to wash and to change their clothing; and there shall be provided and conveniently located, seats sufficient to comfortably seat such females, and when such females are not necessarily required to be upon their feet they shall be allowed to occupy such seats; and where persons of both sexes are employed, separate water closets shall be provided for the use of the employees of either sex.

(6.) Sanitation,-All establishments must be kept clean and sanitary, and proper exhaust fans shall be provided for removing dust from dust-creating machinery. 
(7.) Mining regulations, - Every such corporation operating any mine employing fifteen or more persons, shall cause to be prepaređ, on a scale of not less than 200 feet to the inch, an accurate map or plan of such mine, to be revised at least once in every six months, showing all the workings of such mine, and copies of such maps shall be kept where they can readily be inspected at the mine; such mine shall have at least two escapement openings from each seam, separated by natural strata of not less than 100 feet in thickness, and shall be ventilated by such artificial means as will furnish not less than 100 cubic feet of fresh air per minute for each person employed, and the air current shall be measured by an anemometer at least once a week, arid record made thereof; doorkeepers shall be provided for the most important passages, and the doors used to control ventilation shall be hung so as to close automatically; and all abandoned passages shall be securely closed, and where old workings are approached, bore holes, not less than 20 feet deep, not more than eight feet apart, and sufficient in number to insure safety to the workmen, shall be kept in the face and side walls in advance of the workings; where there is danger from fire-damp or such noxious gases, such mine shall be examined every morning before the miners go to work, by means of safety lamps which shall be owned and under the control of the mine owners; such mines shall be properly drained; the roof and walls shall be at all times supported in such way as to prevent injury from falling material, and an adequate supply of timber for props shall be constantly available; all passage ways through which the cars pass shall have shelter holes or retreats in the sides, not more than 30 feet apart, into which the miners may retreat to avoid passing trucks or cars; a cage, equipped with safety catch appliances, and having a metal top, and connected to at least two cables, attached to a cable drum provided with flanges and brakes, shall be used to raise and lower the workmen in the mines, during which no material shall be raised or lowered; metal speaking tubes, or other effective means of vocal communication between the top and bottom of shafts, shall be provided and a code of signals adopted and used to regulate the movement of the cages up and down the shafts; no employee shall burn any oil in the mines composed wholly or in part of petroleum or its products, but such oil must be at least seventy-five per cent. pure lard; but this shall not prevent the use-of "Sunshine" as an illuminant. All mining rules shall be conspicuously posted at the 
mine, and shall be easily accessible to all employees. The underground operations of all such mines shall be in charge of a competent superintendent, who shall be charged with the special duties of seeing that all rules are complied with, the requisite amount of ventilation is provided, that the walls and roofs are properly timbered, and that the hoisting apparatus is in proper working order.

(8.) Age and sex of employees,-No corporation formed under this Act shall employ any child under fourteen years of age in any mine, factory, or workshop; and no such child shall be employed in any work whatever performed for wąges or other compensation, to whomsoever payable, during the hours when the public schools which he might attend are in session; and no minor under sixteen years of age, and no girl under eighteen years of age shall be employed at any such work before the hour of six o'clock in the morning nor after seven o'clock in the evening; no minor under eighteen years of age, and no woman shall be employed in any such occupation more than ten họurs in one day, and not more than fifty-five hours in one week.

(9.) Company stores, etc., - No such corporation, nor any one for it, shall by force, coercion; threats, intimidation, or undue influence, of any kind whatever, compel its employees, or any of them, to board at a particular boarding house, rent or live in a particular house or tenement, or trade with or at a particular store of any kind. And such corporation shall be subject to section 10 of the U. S. Arbitration Act of June 1, 1898, c. 370, imposing a penalty for discrimination against members of labor unions, or requiring contribution to beneficial funds, release from liability, or other things therein forbidden.

$\$ 143$. Commissioner of Labor to Enforce. The Commissioner of Labor shall have the power to require reports, make such regulations, and make or authorize to be made, such investigations or inspections of mines, factories, buildings, works, and plants of any such corporation within the United States, as he shall deem necessary in order to ascertain whether the provisions of section 142 are complied."with, and if not, to take the proper steps to enforce the penalties"provided in sections 180 to 182 ; and it shall be his duty to make, or cause to be made, an investigation whenever he is requested to do so, and has reasonable ground to believe such provisions are not being ${ }_{i}^{m}$ complied ${ }_{3}^{n} w i t h$. 
\$ 144. Day's Work. In the employment of workmen by any such corporation, ten hours service to be performed in the day time, shall constitute a day's work, unless the agreement of service shall otherwise provide.

\$ 145. Arbitration of Disputes. (1.) Act of 7898 to apply,-Corporations formed under this Act shall be subject to, and shall have the benefits of, the provisions of the Act of June 1, 1898, c. 370, providing for the arbitration of disputes between carriers engaged in interstate commerce, and the provisions thereof are extended to all corporations formed under this Act; but when the dispute is between a trading corporation and its employees the Commissioner of Corporations shall perform the duties assigned by that Act, to the Chairman of the Interstate Commerce Commission.

(2.) Compulsory, when,-Whenever a dispute arises between a corporation formed under this Act and a trade union incorporated under the National Trades Union Act of June 29, 1886, c. 567, 24 Stat. $86^{\circ}$, or between such corporation and any other trade union which tenders a bond in such sum and secured by such sureties as the Commissioner of Corporations, or the Chairman of the Interstate Commerce Commission, and the Commissioner of Labor shall deem adequate made payable to such corporation in case of refusal to abide by the award of arbitrators, and such dispute cannot be settled by mediation and conciliation as provided in said Act of June 1,1898, c. 370 , either party to such dispute may require the same to be submitted to the arbitration of a board of three persons; such board may be chosen, and the terms of submission including the questions to be decided may be fixed as provided in said Act; if not, the party who.wishes to have the dispute arbitrated shall first submit in writing the points in dispute which it desires to have decided, to the otiner party, with a request that said party approve such statement, or formulate one of its own, and also choose an arbitrator in accordance with the provisions of said Act. The party making such request shall within ten days thereafter choose an arbitrator in the manner provided in said Act; and if the other party fails to comply with such request to choose an arbitrator for fifteen days, the party making the request shall apply to the judge of the United States District Court of the district wherein the dispute arises, who shall within five days there-after name an arbitrator on behalf of the party so neglecting or refusing; the third member of the board shall be chosen as pro- 
vided in said Act; such board shall have full power to fix the time and place of hearing, to notify the parties thereof, and to hear and determine in full the matters in dispute contained in the written submission of the parties, or upon the statement made by the party requesting arbitration, if the other party has or has not approved it, or has or has not formulated a statement of its own, and if so, upon all matters that may be in controversy between the parties, in such manner in all respects as in equity and good conscience, such board thinks fit; the board shall otherwise have the power to, and shall, proceed as provided in said Act, and its award shall be as binding and shall have the same effect upon the parties as if they had expressly made and acknowledged an agreement of arbitration in writing, and stipulated to be bound by the decision of the board thereunder, as provided in said Act.

\$ 146. Employers' Liability. (1.) Death of employee,-Any corporation formed under this Act shall be liable to pay, except as hereinafter provided, to any workman or laborer in its employment, who sustains personal injury arising in the course of such employment, compensation as follows: if death results from the injury, and sich workman leaves any persons wholly dependent upon his earnings at the time of his death, there shall be paid a sum equal to his earnings for the preceding three years, if he had been employed by such corporation for such period, or if not, then 156 times his average weekly earnings while so employed, or $\$ 750$, or whichever sum is the larger, but not in any case more than $\$ 1500$; or if he leaves persons only in part dependent upon him, then the sum shall be fixed by agreement, or by arbitration, to be reasonable and proportionate to the injury to such dependent, but not to exceed the sum allowed in case of those wholly dependent upon such earnings; or if no dependents are left then the reasonable medical and burial expenses not to exceed fifty dollars. Such payments shall be made to the personal representatives of the deceased, if any, for the benefit of the dependent, or to them, or to those to whom they may be due, but such sum shall not be considered as a part of the estate, and subject to the debts, of the deceased.

(2.) Injury without death, - In case death does not result from the injury, but only total or partial incapacity, then during the time of incapacity, a weekly payment of fifty per cent of the average 
weekly earnings for the preceding twelve months, if so long employed by such corporation, or if not then of the average for the period so employed, but in neither case to exceed the sum of $\$ 5.00$ per week; but regard shall be had in fixing such weekly payment to the difference in capacity to earn before and after the accident, and to any sum recovered by such workman, other than wages, from such corporation in respect to such injury. Such corporation shall be liable to the workmen of a contractor or sub-contractor to whom such work has been let by such corporation, if such workmen are injured thereby, to the same extent and in the same manner, as if they had been employed directly by such corporation.

(3.) Not to apply, - No compensation shall be made for an injury which'does not disable such workman for more than three weeks, from earning full wages at the same work, nor for any injury which is due to the serious and wilful misconduct of the workman himself.

(4.) Notice,-Compensation hereunder shall not be recovered unless notice of the accident shall be given as soon as practicable, and not more than six months after its occurrence and before the Wrorkman has voluntarily left the employment of such corporation. The notice shall give the name and address of the person injured, and shall state in ordinary language the cause of the injury, and the date and place where sustained, and the same may be served upon such corporation by the party entitled to compensation as is provided in section 88 (3), for serving summons.

(5.) Other liabilities, - Nothing herein shall affect the civil liabilities of such corporation for damages due to the negligence or other wrongful act of such corporation, or its agents or servants, but the right to maintain an action therefor shall remain the same as heretofore, and proceedings may be had hereunder or otherwise; but proceedings bad under one with full payment thereof, shall be a bar to proceeding under the other; if, however, damages under a supposed civil liability are sought to be recovered in an action which fails, such failure shall not be a bar to the right of compensation hereunder, and if the plaintiff so demands the court may assess such compensation, and may deduct therefrom the costs caused by the plainliff bringing an action for damages, if in its judgment justice so requires.

(6.) Waiver, - No contract or agreement of any kind whatever made with such corporation whereby such workman agrees to waive or relinquish such compensation for injury as herein pro- 
vided, or any civil liability for damages due to the wrongful or negligent act of such corporation, or its agents or servants, shall be of any validity whatever.

(7.) Insurance, - Such corporation shall be deemed to have an insurable interest in the safety of its workmen, and may insure itself against the liability herein created; but the party entitled to compensation shall have a prior claim upon the amount due the employer from any iusurance company because of an injury to any workman.

\section{Annual Report.}

$\$ 147$. Required in all Cases. (1.) Transportation,-Eivery transportation or transmission corporation organized under the provisious of this Act, shall be required to make and file with the Interstate Commerce Commission, an annual report for the fiscal year ending June thirtieth of each year, such as may be required by such commission under the provisions of this Act and those of the Interstate Commerce Act, and the amendments thereto.

(2.) Trading,-Every trading corporation organized under the provisions of this Act, shall be required to file annually with the Commissioner of Corporations, such a report as may be required by him under the provisions of the Act creating the Deparment of Commerce and Iabor, and the amendments thereto.

(3.) Contents, - In any event such report, whether of ia transportation, transmission, or a trading corporation, shall include the following:-

(1.) The name of the corporation.

(2.) The location, town or city, with street and number of the registered office, with the name of the registered agent therein.

(3.) The names and post office addresses (other than the registered office) of all the direciors and officers of the corporation at the time the report is filed, and the date of the expiration of their term of office, together with a copy of the alphabetical list of shareholders, made, used and filled in by the inspectors at the annual election, as provided in section 113.

(4.) The character of the business or businesses carried on by the corporation.

(5.) The location of any and all transfer offices.

(6.) A correct copy of the last shareholders' balance sheet and report. 
(7.) The market value of all outstanding shares, bonds and. debentures, as of the preceding thirtieth day of June, specifying the amount of each, and the total of all.

(8.) The total assessed valuation of all the property of such corporation as made by state assessors for taxation at the last appraisement, indicating the amounts in each state, and the total of all.

(9.) The total cost of permanent improvements made during the year, and paid for out of the income from operations and investments.

(10.) The date of the next annual shareholders' meeting for the election of directors.

(11.) A list of the dates of the certificate of incorporation and the amendments thereto, in chronological order.

\section{Taxation.}

\$ 148. Method. (1.) Property, by states,-Corporations organized under this Act shall be subject to a franchise fee, and taxation as herein provided, and in no other way: All corporate property, real, personal, mixed, tangible, and intangible, not including the corporate franchises, good will, capital stock, and shares in the hands of the shareholders, shall be subject to a taxation by the state where the same is located, provided the same is assessed in the same way and no higher than other property of like kind used in a similar way, within the state, and the rate of taxation on the same is no greater than on similar property, similarly located, used for similar purposes; this provision shall not prevent the states from assessing the corporate property in the state as a part of a whole devoted to the corporate purposes, and notmerely as isolated pieces of property; such property shall not be taxed by the national government.

(2.) Franchise, by United States,-valuation, rate,-An annual franchise or license fee to engage in national commerce shall belaid and collected by the national government, as follows: The total cash value of the outstanding shares of all classes, or substitutes therefor of any kind, and of all outstanding bonds, mortgages, debentures, certificates of indebtedness, receiver's certificates, scrip, or other evidences of debt, convertible into shares or bonds, or similar obligations, or having three or more years to run, shall be obtained, as of June thirtieth of each year. From the sum so 
obtained there shall be subtracted the total assessed value of all the corporate property as fixed by the various states, and upon which taxes are paid by such corporation; at the time of the last prior appraisal thereof. The remainder shall be considered to be the value of the corporate franchise and good will, and there shall be charged and collected thereon an annual license fee at the following rates: Upon each $\$ 1000$ up to $\$ 5,000,000$, one dollar; for each $\$ 1000$ between $\$ 5,000,000$ and $\$ 10,000,000$, one dollar and fifty cents; for each $\$ 1000$ between $\$ 10,000,000$ and $\$ 15,000,000$, two dollars; and so on, the rate per $\$ 1000$ increasing fifty cents for each $\$ 5,000,000$ increase in the value of the franchise. 2

(3.) Statement, -On or before Juiy I5th of each year, such corporation shall make and file with the Collector of Internal Revenue of the district in which such corporation has its registered office, a true and accurate statement, verified under oath by the president or chief officer thereof, which shall set forth upon blanks to be provided by the Commissioner of Internal Revenue, with the approval of the Secretary of the Treasury, and under such rules and regulations as such officers may prescribe, the total amount of authorized capital stock of each class, the amounts thereof outstanding, the amount paid thereon, and the market value thereof; likewrise the same information as to all bonds, debentures, and obligations outstanding; also an itemized statement of all the corporate property, the states in which it is located, the value thereof, and the assessed value thereof by the states in which taxes thereon are paid by such corporation, the amount of taxes paid thereon, and such other items as such officers may prescribe as necessary to enable them to determine the value of the franchise as hereinbefore provided.

(4.) Assessment,-Such collector shall transmit such statement to the Commissioner of Internal Revenue, as in other cases, who shall cause the amount of the franchise or license fee due for the year by such corporation to be determined as provided herein.

(5.) Collection,-Such commissioner shall cause the amount so fixed to be certified to the collector of the district wherein the registered office is located, for collection by him. Such tax shall be due and payable on or before the first day of January in each year, and for failure for ten days after notice and demand, such cor-

1 Scenote to $\$ 80$. 
poration shall be subject to the same penalties as in other cases, and, upon suit by the attorney-general, such corporation may be enjoined from engaging in national commerce until the tax is paid, or it may be dissolved.

(6.) Revenue lazes to apply,-All the provisions and penalties imposed by the laws of the United States relating to the powers of the internal revenue officers, collectors, and agents, the assessment, collection, and payment of the taxes imposed thereby, the obtaining the necessary information or the witholding, refusal, or neglect to give the same, or to make returns required, or making false returns, made in other cases, so far as the same may be applicable, except as herein modified, shall apply to the franchise fee imposed herein, as fully as if such provisions were specifically referred to or incorporated herein.

(7.) Shares exempt, - The shares of stock and the bonds and obligations of such corporation, upon which the value of the franchise has been based as herein provided, outstanding in the hands of the owners thereof shall not otherwise be subject to taxation or charge of any kind by the states or the national government; but this provision shall not be construed to create a contract the obligation of which shall not be impaired.

\section{Judicial Contral:}

§ 149. Quo Harranto. Any such corporation shall be subject to dissolution by a proceeding in the name of the United States, in the form of an Information in the nature of Quo Warranto, brought by the attorney-general of the United States in the circuit court of the United States in the district in which said corporation shall have its registered office, against such corporation for abuse, misuse, nonuse, usurpation, ultra vires or illegal or fraudulent acts or transactions in violation of the franchises conferred upon such corporation, or for violations of the duties placed upon such corporation by the provisions of this Act, or for failing to begin business within two years after incorporation, or suspending business for one whole year, or whenever the membership falls below seven; and the same action may be brought against those who assume to act as such corporation without being legally incorporated, and such suit may be brought against such parties in the name of the pretended corporation without naming, the individuals composing it, and bringing suit in such name shall not be a recog- 
nition of the validity of the existence of such pretended corporation. Judgment of dissolution for, or ouster from, or injunction against, the exercise of any power, privilege, or franchise claimed or attempted to be exercised, or for failure to conform to the provisions of this Act, may be rendered and enforced by such court.

\$ 150. Mandamus. Whenever any such corporation lies under a specific duty, whether public or private, expressly or impliedly placed upon it by its charter, or by this Act, or by any law of the United States, or by the common law, and there exists no complete and adequate remedy by the ordinary course of procedure, such duty may be enforced by proceedings in mandamus by the attorneygeneral in the name of the United States, if the duty is a public one, and in case the duty is a private one then in the name of the United States on the relation of the person whose right is affected, provided that, in the latter case, suit is commenced within six years after such corporation first refuses to perform such duty.

$\S$ 151. Injunction. An injunction may be granted upon application of the attorney-general, on behalf of the United States, against any such corporation whenever it is abusing or misusing any of its powers, or engaging in ultra vires acts, or acting to the detriment of the public, or creating a public nuisance, or threatening to do any of these.

$\S$ 152. U. S. Circuit Courts to Have Jurisdiction. Such mandamus or injunction proceedings shall be brought in any circuit court of the United States in the district where the question arises, and where jurisdiction of the parties can be obtained as in other cases. Jurisdiction is hereby conferred upon the circuit courts of the United States to hear and determine all such complaints by information in the nature of quo warranto, mandamus, and injunction as hereinbefore provided, under such rules of procedure as are now, or may be prescribed by the Supreme Court of the United States.

Appeals 'may be prosecuted from the circuit court as in other cases; but in matters not constitutional, arising wholly under this Act, the circuit courts of appeals shall have final jurisdiction.

IX. RIGETS AND LIABIIITIES OF MERMBERS.

\section{Rights.}

\& 153. Certificate of Stock. (1.) Each person who is accepted as, or becomes, a member of a corporation formed under this Act shall be entitled to a certificate of stock stating the things indicated, and executed as provided, in section 52 . 
(2.) Lost certificate, - In case a certificate has been lost or destroyed the by-laws may prescribe the terms and conditions upon which a new certificate of stock may be issued in the place of the old one. In the absence of any such provision, the directors may in their discretion, require the owner of a certificate alleged to be lost or destroyed, or his legal representatives to give a bond with sufficient surety to the corporation in a sum not exceeding double the market value of the stock, to indemnify the corporation against any loss or claim which may arise by reason of the issue of a certificate in place of such certificate supposed to be lost or destroyed.

\$ 154. Yoting. (1.) Proxy, -Unless otherwise provided in the charter, at every shareholders' meeting each stockholder (except as herein limited), shall be entitled to one vote, in person or by proxy given in writing, for each share held by him. Every proxy shall be dated and shall state the meeting in which it is to be used and no proxy shall be valid after the final adjournment of such meeting, nor shall any proxy be voted by any candidate for election as a director.

(2.) Trustee,-Every person holding stock as executor, administrator, guardian or trustee, or in any other fiduciary capacity may represent the same at all meetings of the corporation and may vote thereon as a stockholder; and every person who shall pledge his stock may represent the same and vote thereon at all meetings unless in the transfer to the pledgee on the books of the corporation he shall have expressly empowered the pledgee to vote thereon, in which case only the latter or his proxy shall represent and vote such stock.

(3.) Unpaid, - No share upon which any sum is due and unpaid, shall be voted by the owner thereof, or any one for him. .

(4.) Stock held by corporation,-Shares of its own stock belonging to such corporation, or held in trust for, or controlled by, it shall not be voted upon directly or indirectly.

(5.) Shares held by other corporations, - Shares held by other corporations in violation of section 87 shall not be voted upon directly or indirectly.

(6.) Personal interest, -The personal interest of any sharehoider in the subject matter to be voted upon, if exercised in good faith and not in fraudulent disregard of the rights of others, shall not disqualify any shareholder from casting his vote as he may choose.

(7.) Voting trusts, - Any voting trust, combination, or contract, among members whereby less than a majority of all the outstanding 
shares shall determine the vote to be cast by such majority, or shall be authorized to cast the vote of such majority, shall be void; no party thereto shall be bound thereby, and any dissenting shareholder may enjoin the casting of such vote, and any action based thereon.

§ 155. Dividends. (1.) Only out of profits,-Any corporation organized under this Act may declare and pay dividends out of its surplus earnings or net profits arising from its business; but such corporation shall not divide, withdraw, or in any way pay to the stockholders, or any of them, any part of its capital or reduce its capital stock, except as provided in this Act.

(2.) Reserve fund; division of profits, - No dividend shall be declared on any stock in any year until a reserve fund amounting to at least twenty per cent of the face value of the outstanding stock is set aside, and then only out of the surplus profits over and above that sum; thereafter at the first meeting of the directors after the annual meeting, unless the by-laws otherwise provide, or unless otherwise directed by the shareholders, after reserving such other sum out of the profits as the shareholders shall direct for working capital, or as an additional reserve or sinking fund or for betterments or improvements, the directors shall make a diyidend among the stockholders of at least fifty per cent of the net profits over and above such reservations, and in case the directors refuse or neglect to do so, the circuit courts of the United States having jurisdiction of the parties shall have equitable jurisdiction, upon application of such corporation or a shareholder to order the declaration and payment of such dividend.

(3.) To be pro rata,- When dividends are declared, they shall be, among the same class of shareholders, pro rata and equal, and without preference, upon the face value of the shares; but if expressly. so provided in the by-laws, and so stated in the certificates of shares, dividends may be declared and paid in proportion to the amount paid upon the shares.

(4.) Quarterly or semi-annually,-Subject to the foregoing provisions, dividends may be paid semi-annually, or quarterly on preferred stock as such stock may provide; and thereafter, a like, but no greater, amount, may be likewise declared and paid on the common stock, if the directors so decide, and the by-laws so provide, without waiting till the end of the fiscal year; but at the end of the fiscal year, the full amount of the surplus earnings after payment in full of the preferred dividends, and of other prior obligations, may, 
unless otherwise provided, be distributed among the holders of the common stock; but whether such distribution shall be made, except as above provided, ślall be in the discretion of the directors.

(5.) Money or stock,-Dividends may be made payable in cash, in stock, in bonds or scrip, or in property, subject to the provisions of sections 46 to 48 , and 87 .

(6.) Who entitled to,-The owner of the stock at the time the dividend is declared shall; in the absence of a contract to the contrary, be entitled to the dividend, whenever earned (except. as hereinafter provided), and whenever to be paid; but the corporation in the absence of any notice of the previous sale of the shares, or in case of any transfer of the certificate after the closing of the books before dividend days, may, without further liability, pay the dividend to the person shown by the transfer bouks of the corporation, to be the owner of the shares at the time the dividend was declared,-but the real owner of the shares at the time the dividend was declared may maintain an action against the party to whom it was paid to recover the amount thereof.

(7.) Life tenant,-As between a life tenant and remainder man in the ownership of stock, when the life tenant is entitled to the income of the shares, all dividends which shall be declared out of or based upon the net earnings or profits of the corporation arising after the beginning or during the continuance of the life estate, in whatever form they may be declared, shall go to the life tenant; but all distributions of the capital of the corporation shall go to the remainder-man as a part of the corpus of the estate.

(8.) Effect of declaration,-When a dividend is declared by the directors and the corporation then has the funds with which to pay the same, the declaration of the dividend shall be considered as the setting aside and appropriating of the sum of money necessary to make payment thereof, which sum shall thereafter be held to belong to the shareholders entitled to such dividends.

(9.) Payment,-When a dividend is due arid unpaid, upon demand made, the shareholder entitled to the same, may maintain an action therefor against such corporation in any court having jurisdiction of the parties.

$\S$ 156. Inspection of Books. (1.) Right to,-All the corporate books and records, including the account books and mortgage record, shall at all reasonable times during business hours be subject to the inspection of any shareholder who shall-not be required 
to give any specific reason therefor; such inspection may be made by any shareholder in person, or by an agent duly appointed in writing by such shareholder for such purpose; and copies of such documents, or any part thereof may be taken; but such inspection or examination, if it interferes with the proper keeping of the accounts shall not occupy more than one hour in each day.

(2.) Remedy for refusal,-If any officer or agent of such corporation having charge of such books or records refuses or neglects to exhibit or to submit them to examination as aforesaid, he or the corporation shall be liable to any stockholder for all actual damages sustained by reason of such refusal or neglect, and upon petition of any stockholder, any circuit court of the United States, having jurisdiction of the parties, shall have jurisdiction in equity to order any or all of said records to be exhibited to such stockholder, and to such other stockholders as may become parties to such petition, or to their agent, at such a place and time as the court shall deem just and right.

(3) Copies of certificate of incorporation and by-laws,-Eivery stockholder shall be entitled to receive, and every corporation, by its officers and board of directors shall be bound to furnish to any stockholder on request, at the expense of the corporation at least one copy of the certificate of incorporation, and of the by-laws, and of all amendments to either of the same.

(4) Statement as to salaries, - Any stockholder shall be entitled, upon payment of cost of copying at not over ten cents per one hundred words, to a statement at any time, of all salaries paid to any officer or officers of the corporation, together with a statement of all contracts or agreements in which any officer of the corporation may be interested either as a contracting party with the corporation, or as an officer or stockholder in any other company contracting with the corporation.

(5) Balance sheet,-Every stockholder shall be entitled to receive a copy of the shareholders' balance sheet, as provided in section $132,(2)$.

\$ 157. Transfer Shares. Unless otherwise provided in the agreement of Association, or amendments thereof, and stated in the certificate of stock, shareholders shall have the right to transfer their shares as hereinafter provided subject to the following limitations.

(1) Limitations, - Stock which is not fully paid shall not be issued or transferred to any person who is insolvent or incompetent 
to assume the obligations of a shareholder, and to pay any call that may be made upon such stock, and the corporation or any agent thereof may refuse to transfer or register the same upon the corporate books; any officer or agent who knowingly or negligently registers such transfer shall be personally liable to the corporation for the payment of any call thereafter made,so long as the stock remains in the name of such, or any other,incompetent person, and unpaid; and all transfers of stock to any person unable or incapable of assuming and discharging any liability thereon, for the purpose of evading such liability shall be void. Shares claimed to be owned by other corporations contrary to the provisions of section $87,(7),(8)$, shall not be transferred on the corporate books, and such sales or attempted sales shall not release the former owner from liability thereon. Stock shall not be transferred after the corporation becomes insolvent except by consent of the receiver selected to wind up the corporate affairs as hereinafter provided.

(2) Delivery of certificate, - The delivery of a certificate of stock by the rightful owner thereof, or by a person entrusted by him with its possession for any purpose, to a bona fide purchaser or pledgee for value, with a written transfer thereof, or with: a written power of attoruey to sell, assign, or transfer the same, signed by the person named as the owner thereof in such certificate, shall be sufficient delivery to transfer the title thereto for the purposes therein named, as between the partiesthereto, or any one claiming under them, and except as hereinbefore restricted shall entitle the transferee thereof to be registered on the corporate books as a shareholder.

(3.) Transter on books, - Shares of stock shall be transferable on the books of the corporation, with the foregoing limitations, in such manner and under such regulations as the by-laws provide; but in any event, the transfer shall be made upon a proper transfer book kept for that purpose, and shall be accompanied by the surrender of a duly endorsed certificate representing the shares transferred, with a power of attorney authorizing the transfer to be made on the corporate books; the surrendered certificate shall be canceled and attached to the corresponding stub in the stock certi- 
ficate book, and a new certificate shall be issued to the party entitled thereto.

(4.) Effect of registration, - The date of the tender or surrender of the certificate to the corporation for the purpose of having it transferred, if the transfer is afterward completed shall, so far as the corporation is concerned be deemed to be the date of the beginning of the membership of the transferee, and the termination of the membership of the former owner; and the delivery of the certificate by the seller to the purchaser for the purposes of transferring the shares, shall not affect the right of the corporation to pay any dividend due on such shares, or to treat the holder whose name is on the record as the holder in fact, until such certificate, - properly indorsed, with the power of attorney to transfer, is presented and transfer on the books is demanded.

(5.) New certificate to issue,-The purchaser of shares, upon the production and surrender of the certificate, properiy indorsed, and accompanied with a proper power of attorney to the transfer agent of the corporation, shall be entitled to a new certificate.

(6.) Pledge of shares,-A pledgee of stock transferred as collateral security shall be entitled to a new certificate if the instrument of transfer shall substantially describe the debt or duty which is intended to be secured thereby. Such new certificate shall express on its face that it is held as collateral security, and the name of the pledgor shall be stated thereon, and he alone shall be liable as a stóckholder, and entitled to vote thereon except as provided in section 154(2).

(7.) Corporate books as evidence,-As against the corporation, and between the sbareholders and third parties the entries upon the corporate books shall be prima facie evidence of membership.

(8.) Transfer agent, - Such corporation may appointan individual or corporation as its transfer agent or as registrar of the stock, and require the issue and transfers of stock, bonds, and debentures to be signed or countersigned thereby. And any one so signing as transfer agent or registrar shall be deemed to guarantee the legality and regularity in all particulars of the transfer, unless the signing or countersigning shall, in clearly legible characters, give notice to the contrary.

(9.) Closing books, - The by-laws may provide for the time of closing the stock and transfer books before general election or divi- 
dend days, but in the absence of special provisions therefor they shall be closed fifteen days before such days.

(10.) Remedy for refusal to transfer, - Every bona fide purchaser of shares of stock who has complied with all the provisions of this Act, and the requirements of the by-laws relating to the transfer of ${ }^{\circ}$ shares, upon the corporation or the transfer agent refusing to transfer the shares to him upon the corporate books, issue to him a new certificate therefor, and recognize him as a member, may have a writ of mandamus against such corporation or agent, upon a proper application to the United States circuit court having jurisdiction of the parties, to compel such transfer and recognition, and the issue of a proper certificate.

Seller,-Iikewise the person who has sold said shares to a purchaser capable of taking them, may have a writ of mandamus to have his name removed from the books of such corporation as a stockholder therein.

(11.) Effect of completed transfer,-A transfer of shares completed in accordance with the foregoing provisions shall release the seller from any further liability to the corporation or to any of its creditors, and all such liability shall attach to the transferee; but in case such shares are issued as full paid, when in fact they are not so, the original owner thereof, or any transferee with knowledge of the facts, who transfers them to any one who does not know them to be unpaid, shall be liable to such transferee for any sum he may have to pay thereon, and shall also be liable to the corporation, if neces: sary to pay creditors thereof, to the extent the stock was unpaid.

$\S$ 158. Participate in Increase of Stock. Unless otherwise provided in the amendment authorizing an increase of stock each solvent shareholder shall have the right to subscribe at par to such increase in -proportion to the number of shares owned by him if all the outstanding shares are fully paid, or if all such shares are paid up to the same extent; otherwise only in proportion to the amount such shareholder has paid upon his shares; and for failure or refusal by the corporation or its officers to allow such subscription to be so made, the shareholder may, upon application in equity, to any circuit court of the United States, having jurisdiction of the parties, enjoin the issue and distribution of such shares until he shall be given his due proportion.

$\S$ 159. Sue in Equity for Hrongs to Corporation. (1.) Uttra vires acts,-Any shareholder may maintain a suit in equity in any circuit 
court of the United States having jurisdiction of the parties, against the corporation or its officers or agents to enjoin it or them from engaging in, or carrying on, or continuing in an ultra vires executory undertaking or transaction.

(2.) Wrongs and frauds of corporate authorities, - Any bona fide shareholder, who, after making diligent effort to obtain a remedy through the officers, directors, or shareholders of the corporation, fails to obtain such relief; or who is able to show that it would be impossible to obtain such remedy through such channels; or who can show it would be unsafe to wait until such remedy could be so obtained or would be unreasonable to require him to seek such a remedy, may, upon behalf of himself and all other shareholders who have not been. a party to such wrongful acts as hereinafter set forth, and who shall share in the expenses of such suit, maintain a suit in equity in any circuit court of the United States having jurisdiction of the parties, against such corporation and the wrongdoers or any of them, for wrongs threatened, or done to, or suffered by, such corporation arising from, (1) some action or threatened action of its board of directors beyond the authority conferred upon them; or (2) any fraudulent transaction, or transaction in breach of the trust confided in them, completed or contemplated by the directors, officers, managers or agents of such corporation, with other parties, among themselves, or the other shareholders, as will result in serious injury to the corporation, or to the interests of the complaining shareholders; or (3) where such directors, officers, managers or agents wilfully misapply or divert the corporate funds, or in breach of the trust confided in them, negligently allow the corporate funds to be misapplied or diverted so as to seriously injure the interests of the corporation or the shareholders; or (4) where such directors, officers, managers or agents, or a majority of them are acting for their own interests in a manner destructive of the corporation itself or of the rights of the shareholders; or (5) where the majority of the shareholders themselves are oppressively and illegally pursuing a course in the name of the corporation which is in violation of the rights of the other shareholders; to enjoin the completion or continuance of such threatened wrong and to compel restitution and compensation to be made therefor.

$\$ 160$. Distribution on Dissolution. In case of dissolution or the reduction of the capital stock of the corporation, and a distribution of part of the capital, the shareholders shall share in the division of the sum 
to be distributed in accordance with the preferences provided in the issue of the shares, if any; but if no such preference was provided for, the payments made on the shares shall first be equalized, and the balance distributed-pro rata according to the face value of the shares; and the same method shall be applied, unless otherwise originally provided, in the distribution among the owners of shares entitled to preferences.

\$161. Contribution. In case any shareholder shall be held to pay more than his proportionate amount in discharge of the debts of the corporation, he shall be entitled to contribution from the other shareholders, and may maintain actions against the same for their proportional amounts.

$\S 162$. Enjoin Changes. Any bona fide shareholder may enjoin any change, amendment, or modification of the charter or by-laws of the corporation, unless the same shall be made in accordance with the provisions of this Act; and in any case of a material amendment made as provided in section 94 , or consolidation as provided in sections 96,97 , or selling out as provided in section 99 , any dissenting shareholder who declares his dissent in writing at the meeting authorizing such amendment, consolidation, or selling out, may enjoin the same, until such corporation first pays him the full market value of his shares to be fixed by three disinterested appraisers appointed by the circuit court of the district in which the registered office of the corporation is located upon application of such shareholder or shareholders, and on reasonable notice to be fixed by the court and given to the corporation. .

\section{Liabilities.}

§ 163. On Unpaid Shares. Every shareholder whose shares havenot in fact been fully paid, whether issued for cash, property, services or otherwise, and whether part of the original issue or an increase thereof, or whether held by the original owner or a subsequent transferee, shall be- liable to pay up, if necessary to discharge the corporate obligations incurred after the issue of such stock, the full face value thereof, or such part thereof as may be needed therefor, after the other corporate assets are exhausted. But trustees shall be liable only to the extent of the trust estate.

$\S 164$. Withdrawing Assets. Any stockholder who shall receive any part of the capital of such corporation by way of dividend, loan, or otherwise, unless the same shall have been paid to him in the 
redemption of his shares or by way of reduction of the capital stock of such corporation as provided in sections 44,95 , herein, shall be liable to refund the amount so received, or so much thereof as may be needed therefor, to the corporation whenever the same shall be necessary to discharge the obligations of the corporation existing at the time of, or incurred subsequent to such dividend or payment.

X. OFFICERS' RIGHTS AND ITABIIITIES.

\section{Rights.}

$\S 165$. Manage. The directors, officers, and agents of the corporation, so long as they hold their offices shall have power, in good faith, within the scope of the authority delegated to them, to manage the ordinary corporate affairs in accordance with the provisions of this Act, without interference on the part of shareholders or others.

\$ 106. Contracts With Corporation. Any contract made by or on behalf of the corporation by an officer thereof, in which he shall have a personal interest, or in which the directors or any of them may be personally interested, and whose presence was necessary to constitute a quorum of directors, or whose vote was necessary to such action, or between corporations represented by the same persons, or having common directors whose presence was necessary to a quorum, or whose votes were necessary to such action, may be avoided by the corporation, or by any shareholder thereof not a party thereto, on behalf of the corporation, provided the same shall not be, or have been, authorized by the shareholders before, or ratified or acquiesced in by a majority of the shareholders, after full report thereof and of such"officers' interest therein has been made to a meeting of the shareholders. But nothing herein shall prevent the making of a valid contract between such corporation and any of its corporate officers and agents when'such corporation is fully and completely representer by corporate officers and agents having no interest in such contract, and laving the authority to make the same on behalf of the corporation.

$\$ 167$. Salaries. The directors and general officers of the corporation shall be entitled only to such salaries as may be fixed in the by-laws, or by resolution of the shareholders; but, subject to the approval of the shareholders, the salaries of all other officers and agents may be fixed by the directors. 
\$ 168. Resignation. Every director and officer shall have the power at any time to resign from his office, and no acceptance shall be recessary to complete the same, providing such officer shall file notice thereof in the registered office of the corporation; and within thirty days thereafter a like notice in the office of the Commissioner of Corporations, and in the office of the Secretary of the

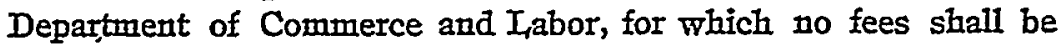
charged. Until such notices are so filed, and until all the obligations incurred by such officer before his resignation, are fulfilled, he shall not be in any wise relieved from responsibility upon such obligations.

\section{Liabilities.}

\$ 169. To the Corporation. (1.) Frand and negligence,-The directors and officers of such corporation shall be deemed to stand in a fiduciary relation thereto, and shall be bound to exercise good faithand the ordinary skill and diligence that prudent business men exercise in the conduct of their own affairs of like kind in the management, control, and supervision of the affairs, business, and the subordinate officers and agents of such corporation, and shall be jointly and severally liable in damages for fraud, embezzlement, wilful misconduct, or breach of trust committed for their benefit; ultra vires acts and transactions; giving away or disposing of the corporate funds without proper consideration; inattention, nonattendance or negligence allowing fraud or misconduct on the part of agents, officers, or co-directors, or resulting in the diversion, misapplication, dissipation, or waste of the corporate funds, and which could have been prevented by the exercise of ordinary care and attention to the corporate business; but no director, - or officer, shall be so liable unless his own act, default, or negligence has contributed to, or made possible, such loss or damage to the corporation.

(2.) Enforcement, - Such liability may be enforced by the corporation in any proper form of action in any circuit court of the United States, having jurisdiction of the parties; or in case the . corporation cannot or will not act, then a shareholder not consent-. ing thereto may bring such action on behalf of the corporation as provided in section 159; or the receiver of the corporation appointed to wind up the corporate affairs, may maintain an action against such offending officers, on behalf of the corporation, its shareholders and creditors. 
\$ 170. To Shareholders and Purchasers.. (1.) False statements,The promoters, directors, president and secretary, who sign the Articles of Organization, or the Prospectus, shall be jointly and severally liable to any shareholder or purchaser of shares, bonds, debentures, for actual damages caused by the falsity of any statement contained in such documents, and which they know, or could by ordinary care know, to be false.

(2.) Watered stock and bonds,-For issuing stock, bonds, or debentures, unless cash, property, services, or expenses equal to the face value of such stock, bonds, or debentures ( $\$ 46$ to 48) have been received or incurred by, or conveyed to the corporation, the president, secretary, and directors consenting thereto, shall be jointly and severally liable to any non-consenting shareholder or bona fide purchaser for value, for actual damages caused thereby. But any such officer may cause his dissent to be registered on the records at the time such action is taken, and if so entered in good faith, he shall not be liable thereon.

(3.) Particular wrongs to shareholders,-For failure or refusal to issue a certificate as provided in sections 153 , or to receive the vote of a shareholder as provided in section 154, or to declare or pay dividends according to section 155 , or to allow the records, papers, and books to be inspected or copied, or to furnish the copies required by section 156 , or to transfer shares according to section 157, or to allow subscriptions to increases of stock to be made according to section 158, the officers or agents whose duty it is to recognize these rights of, or perform these functions for, the shareholders shall be liable for the actual damages to any shareholder resulting from such failure, refusal, or neglect, to be enforced in any court having jurisdiction.

$\S$ 171. To Creditors. The officers and directors of every corporation, who authorize, participate in, or consent to any of the follow ing acts or defaults, done or suffered during their period of holding office, shall in the event of the insolvency of such corporation, be jointly and severally liable for the debts and contracts of such corporation to the extent indicated:

(1.) Watered stock and bonds,-If stock, bonds or debentures are issued in violation of sections 46 to 48 , to the extent necessary to pay the debts in full.

(2.) False reports, - If any certificate, notice, statement, or report, which is required by the provisions of this Act to be filed 
with or made to any public officer is false in any material representation, and known to be, or with reasonable care could have been known to be so, to the extent necessary to pay such debts in full.

(3.) Management of funds, - For paying a dividend when the corporation is, or is thereby. rendered, insolvent, or paying dividends out of the capital of the corporation contrary to section 155, to the extent of the dividend so paid; or for loaning money to any - shareholder contrary to section 87 , to the extent of the loan, with interest, until it is repaid in full; or for loss or waste of the corporate funds, by the wilful, or negligent acts or omissions indicated in section 159 , to the extent of the damage done.

(4.) Failure to file reports,-For refusing or neglecting to file the certificates, notices, statements and reports, properly verified, herein required to be filed with any public officer, for sixty days after they are required to be filed, for all debts incurred and contracts made after such failure and before such certificates, statements, etc., are so filed, until the said debts are fully paid.

(5.) Enforcement, - Anp creditor can maintain an action on his own account against one or more of such defaulting officers, or one or more creditors may maintain the action on behalf of all who are injured by such acts, or the receiver may bring suit on behalf of the same, for the damage done such creditor os creditors, in any court having jurisdiction.

(6.) Torts,-Fior any tortious act of an officer or agent, resulting in damage to any person, and not being merely the violation of a duty owed only to the corporation, such officer or agent shall be liable as in other cases.

$\S 172$. Penalties. Officers and agents shall also be subject to the penalties provided in section 181 .

\section{CREDITORS' RIGHTS.}

$\$$ 173. Against the Corporation. Any person having a claim against any corporation formed under this Act may enforce the same in any court having jurisdiction of the parties and the subject matter in any appropriate form of action or suit in equity, including setting aside fraudulent conveyances, or unlawful preferences $(\S 87)$, fictitious mortgage liens ( $\$ 90$ ), bills of discovery or other ancillary proceedings, and have execution or process to enforce the judgment or decree rendered, in the same way and to the same extent as against a natural person. 
\$ 174. Against Corporate Debtors. Any creditor bringing suit against such a corporation may garnishee a shareholder for sums due upon his shares, provided a call has been made therefor and is due and unpaid; and likewise may garnishee any person having property of or who is indebted to such corporation, by first making affidavit to that effect, and proceeding otherwise according to the laws of the state where the suit is brought.

§ 175. Aǵainst Shareholders. Any judgment cręditor who has taken out execution, and the same has been returned unsatisfied, or if the corporation is already notoriously insolvent, or has dissolved without paying its debts or appointed a receiver to wind up its affairs, may, bring suit in equity to enforce the shareholders' liability imposed by sections 163, and 164; other creditors may join in such suit, or upon application, be made a party thereto; or such liability tnay be enforced by the receiver as provided in section 192.

$\S$ 176. Against 0fficers. A judgment creditor or creditors, under the conditions named in sections 175 , 192, may bring suits as therein mentioned to enforce the liability of officers imposed by section 171.

§ 177. Receiver. A judgment creditor who is unable to obtain payment of his debt may under the conditions mentioned in section 186, have a receiver appointed and the corporate affairs wound up as provided in sections 189 to 193.

$\S$ 178. Inspection of Documents. Creditors of the corporation shall at all reasonable times during business hours not exceeding one hour a day, unless otherwise permitted, have the right to inspect the organization papers, lists of officers, and mortgage records, and to copy the same or part thereof, as required by section 128 (1.), (4.) and (6.); for refusal to permit the same to be done the corporation, or the agent so refusing shall be liable to such creditor for the expense of obtaining the desired lists or copies elsewhere, as well as all other damage due to such refusal.

§ 179. Papers Improperly Executed. Corporate officers who execute bills, notes, contracts, invoices, and other like papers without the corporate name appearing thereon as required by section 126, shall be personally liable thereon unless the obligations thereof are discharged by the corporation.

XII. PENAITIES.

\& 180. Against the Corporation. Failure to comply with, or violat- 
ing the provisions of this Act, or refusing or neglecting to perform the duties imposed thereby, by a corporation formed thereunder, shall be cause for proceedings as provided in sections 149 to 152 ; but such proceedings shall not release the penalties otherwise imposed, nor shall collection of penalties bar such proceedings.

Unless otherwise specifically provided stuch corporation shall be liable to the following penalties: For failing to comply with, or violating the provisions relating to the corporate name ( $\$ 36,37$, 126), the registered office ( $\$ \$ 39,41,127$ ), keeping the documents required to be kept therein and allowing them to be inspected and copied ( $\$ \$ 127,128$ ), twenty dollars daily until complied with; for failing to comply with, or violating, the provisions as to prospectus, commencing business, filing notices, certificates and reports required to be filed with public officers, or as to safety of employees, one hundred dollars daily until complied with.

Corporations organized hereunder which shall fail to comply with, or which violate, the provisions of the Interstate Commerce Act, the Department of Commerce Act, or the Anti-trust Act, or the amendments thereto, or any other law of the United States, applicable to similar corporations shall be subject to the penalties therein contained.

§ I8l. Against 0fficers. Except as otherwise provided herein, each officer, promoter, director or agent, upon whom a duty is placed, who fails or refuses to perform the same, as to the corporate name, registered office, keeping doctrments therein and allowing inspection thereof, ( $\$ 36,37,39,41,126,127,128$ ) shall be subject to a penalty of ten dollars daily, until complied with; and for failing to comply with or violating the provisions relating to prospectus, commencing business, filing notices, certificates, reports required, or the provisions relating to safety of employees, shall be subject to a penalty of fifty dollars daily until complied with.

Every promoter, officer, director, clerk or agent of such corporation who shall embezzle, abstract, or wilfully misapply any of the moneys, funds, or credits of such corporation, or shall without authority of the proper officer draw any order, bill of exchange, make any acceptance, assign any note, bond, draft, bill of exchange, mortgage, judgment, or decree or shall make any false entry in any prospectus, book, report, or statement of such corporation, with intent, in either case, to injure or defraud such or any other corporation or company, or any shareholaer, purchaser, creditor, or 
officer of such corporation, or agent appointed or authorized to examine the affairs thereof, or any other person, shall be guilty of a misdemeanor, and upon conviction thereof shall be punished by imprisonment not less than two nor more than ten years.

Every promoter, director, officer, agent or clerk who makes, prepares or swears to false statements, with knowledge of the falsity thereof, in any certificate, notice, or report required to be made or filed herein, shall be deemed guilty of subornation of perjury, or of perjury, and shall be punished as provided in section 5392 of the Revised Statutes of the United States.

Such officers and agents as knowingly participate in the violations of the provisions of the Interstate Commerce Act, the Department of Commerce Act, or the Anti-trust Act, or amendments thereto, shall be liable to the penalties therein imposed on such officers and agents.

$\$ 182$. Against Shareholders. Such shareholders as direct or authorize the violations of the duties herein placed upon the officers and agents of such corporation, subjecting them to penalties, shall be liable to the same penalties.

§ 183. Prosecutions. Prosecutions for the offenses herein mentioned, and the enforcement or collection of the penalties herein imposed shall be brought and conducted by the officers, and in the courts, and with the same effect, as provided in cases of similar offenses under the United States laws.

XIII. DISSOLUTION.

$\S 184$. Methods. Corporations formed under this Act may be dis- solved: (1.) By repeal of its charter as provided in section 134; (2.) by forfeiture of the charter and franchises as provided in section 149, or for failing to commence business as provided in section 83 or for suspending business during the space of a whole year, or whenever its membership falls below seven, as provided in section 149 ; (3.) by voluntary surrender of its franchises and privileges as provided in section 185 ; (4.) by expiration of the period limited in its charter; (5.) by proceedings in court upon failure to pay its debts as provided in section 186.

\$ 185. Surrender. (1.) Before beginning business,-The incorporators named in the Agreement of Association, and all the subscribers to the stock, before any part thereof is paid for, and before beginning the business for which such corporation was formed, may 
surrender all their corporate rights and privileges, by filing in the office of the Secretary of the Department of Commerce and Labor, a certificate signed by all the subscriber to the stock, verified under oath by the incorporators stating that no part of the stock has been paid; that business has not been commenced, and that they thereby surrender all their rights and franchises to be a corporation or to exercise corporate powers under this Act.

(2.) After beginning business, by unanimous consent,-Whenever all the stockholders of any such corporation shall consent in writing to a dissolution, and shall choose a Receiver to wind up the corporate affairs, and such consent with the name and residence of the receiver, with a list of the names and residences of the directors and officers, certified by the president and secretary shall be filed with the Secretary of the Department of Commerce and Iabor, and a copy thereof with the Commissioner of Corporations, the Secretary of Commerce and Labor shall issue a certificate of dissoIution to such corporation which shall cause the same to be published at least oncea week for four consecutive weeks in at least two papers of general circulation throughout the state in which the registered office is located, and thereafter such copporation shall be deemed to be dissolved.

(3.) After beginning business, by two-thirds vote,-Whenever the board- of directors shall deem it advisable that such corporation shall be dissolved, and shall pass a resolution to that effect, a meeting of the shareholders shall be called to take action upon the same, and the same proceedings as to notice, conduct of meeting, quorum, and votes, shall be had as provided in section 94 in regard to material amendments after incorporation. If two-thirds of all the shareholders, and of each class thereof, if there is more than one class, shall vote therefor, 'and shall consent in writing thereto, and shall choose a Receiver to wind up the affairs of such corporation, such consent, with the name and residence of the Receiver and a list of the directors and officers, certified, filed, and a certificate of dissolution issued and published as provided above shall be deemeả to work a dissolution of such corporation.

$\$ 186$. Failure to Pay Debts. Whenever a judgment has been recovered against any such corporation and it has neglected for thirty days after demand made on execution to pay the amount due, with the officers' fees, or to exhibit to the officer real or personal prop- 
exty belonging to it, and subject to be taken on execution, sufficient to satisfy such judgment, and the execution is returned unsatisfied, or whenever it is proved to the satisfaction of the court that the corporation is unable to pay its debts, any circuit court of the United States, having jurisdiction of the parties, shall have authority, upon the application of any creditor or stockholder to make an order to wind up the affairs of such corporation, to appoint a receiver therefor, and decree its dissolution, if the court deems such decree to be just and equitable.

$\S 187$. Date of Dissolution. For the purpose of carrying on its corporate business, such corporation shall be deemed to be completely dissolved if by repeal of its charter, at the date of such repeal; if by forfeiture of its charter by judicial decree, at the date of such decree; if by failing to commence business within two years after incorporation, at the expiration of that time; if by suspension of business for one year, at the end thereof; if by membership falling below seven, sixty days thereafter, unless the membership is increased before; if by surrender, at the date the consent of the incorporators or shareholders shall have been signed by the requisite number; if by expiration of charter, at the date thereof; and if for failure to pay debts, upon the date of the decree therefor.

§ I88. Effect. And thereafter, the power, except as provided in section 192, to continue the corporate business shall cease and determine; those who thereafter carry on, or consent to carrying on such business shall become personally, and jointly and severally, liable thereon; and all transfers of shares, or other voluntary change of status of members shall be void, unless sanctioned by the Receiver; such dissolution, however, shall not affect the rights, duties, obligations and liabilities of such corporation accruing or arising before dissolution.

In every case of dissolution, however, such corporation shall be deemed to be a corporate body for three years after the date of dissolution as above fixed, for the purpose of suing and being sued; and enabling its affairs to be closed up, its property to be properly disposed of or conveyed, and its assets to be collected and distributed as hereinafter provided; but, except in the case of a transportation or transmission corporation, or unless the court otherwise orders, such corporation shall not continue its corporate business.

$\$ 189$. Receiver to be Selected. Whien a corporation is dissolved by order of court, it shall designate a receiver to wind up its affairs; 
in case such corporation is dissolved in any other way, or if the court so allows in the former case, the members of such corporation, if they have not already done so, shall within twenty days after the date of such dissolution, upon call of the president, designate a receiver to wind up the corporate affairs; and upon failure to do so, any circuit court of the United States having jurisdiction, upon the application of the Attorney-General, or any shareholder, or creditor shall appoint such receiver; and such court may at any time for good cause shown, remove any receiver however selected, and appoint another in his place, or may fill any vacancy caused by death, inability or otherwise.

$\S 190$. Bond of Recelver. When the court appoints a receiver, such court shall fix the bond to be given by such receiver, for the faithful discharge of his duties, and the compensation to be paid to him; if the receiver is chosen by the members, they may fix the compensation to be paid to, and the amount of bond to be given by, such receiver; but the court may upon its own motion, or upon the application of any interested party approve or modify the amount of compensation, or the amount of bond, or security given as justice may require.

§ 191. Notice. Such receiver shall immediately after his acceptance give notice of his appointment by publishing notice thereof once a week for at least four successive weeks in at least two newspapers of general circulation in the state in which the registered office of the corporation is located, directing all persons having claims against such corporation forthwith to make proof of the same.

$\S 192$. Powers and Duties of Receiver. Upon the appointment and acceptance of the receiver the powers of the directors shall immediiately cease, and such receiver shall have power, under direction of the circuit coutt of the United States having jurisdiction, either upon his own application, or otherwise.

(1.) To take into his custody all the property, books, papers, and records of every kind belonging to such corporation; and it shall be his duty, with all convenient speed to make and filewith the court a true inventory of all the property of such corporation, indicating the sums unpaid on stock, the amount due upon accounts owing to the corporation, and the damages or claims due from directors, officers, agents, or shareholders, or others, fornegligence, defaults, failure to perform.duties, or other wrongs done to such corporation arising under this Act or otherwise. Also to make and 
file a schedule of the claims of all kinds against such corporation; indicating the securities given therefor, those which he deems it proper to allow, and those that should be contested or denied.

(2.) To bring and defend all actions and all other legal proceedings, civil or criminal, in any court having jurisdiction, on behalf of, or in the name of such Borporation or otherwise, necessary to the proper winding up of the corporate business.

(3.) To carry on the business, and perform the contracts and existing obligations of such corporation, so far as may be necessary to the proper closing up of the corporate business, but not generally to carry it on for profit except by special order of the court. But if such corporation is a transportation or transmission corporation, the receiver shall continue its operation under the direction of the court, so far as may be necessary to perform the public duties incumbent upon such corporation.

(4.) To sell and transfer the corporate property, and execute proper conveyances therefor in behalf of the corporation, in its name, and under its seal if necessary.

(5.) To draw and make bills of exchange, and promissory notes so far as necessary, and may raise money upon the security of the assets of the company if specifically authorized by the court.

(6.) To prove the corporate claims against the estate of any bankrupt or decedent, and to take such steps as may be necessary to protect the corporate rights.

(7.) To make and enforce such calls for unpaid subscriptions as may be necessary to pay the debts or to equalize the burdens of the shareholders.

(8.) To maintain actions against any delinquent promoters, directors, officers, agents, or members, for any violation of their duties to such corporation, the shareholders, or creditors thereof, in whatever manner arising, and to enforce such duties and obligations against the same, or either of them, due to such corporation, or the shareholders, or creditors thereof, under the provisions of this Act, or in any other way.

(9.) To effect such compromise with creditors, debtors, or members, or others in regard to claims by or against the corporation, as the best interests of the corporation, the members, or the creditors may require, subject to the approval of the court; and by the direction and approval of the court may become a party to reor- 
ganization proceedings, and may sell the whole or a portion of the business or property to such reorganized corporation, or to any other corporation, provided the purchasing corporation is organized, and has authority, under the provisions of this Act to purchase the same, in exchange for the shares or other securities of such purchasing corporation.

(10.) To apply to the court in all cases of doubt for directions in closing up the affairs of the corporation.

(11.) To pay such debts of the corporation as shall have been proved within three years after the publication of the notice of the appointment and acceptance of the receiveris completed, and to distribute the property in accordance with the rights of the partie's interested; but the debts and claims shall be paid in the following order:-

(a.) All taxes due by such corporation, whether accruing before or after dissolution.

(b.) The actual cost of preserving the corporate property and carrying on the business so far as is necessary for the proper closing up of the corporate affairs, or performing its public duties.

(c.) The cost of winding up the corporate affairs, and administering the property.

(d.) Wages due to workmen, clerks, or servants, which have been earned within six months prior to the dissolution.

(e.) Debts owing to the United States, or to any state, or to any person who by the laws of the United States or of any state, not inconsistent with this Act, is entitled to priority.

(f.) Debts having a lien, according to the priority thereof, if the same has not been acquired in violation of this Act, or that of any state, and has been duly recorded or evidenced according to this Act or the law of the state where it was created.

(g.) All other debts pro rata, according to their amounts.

So far as the assets will permit, debts may be paid in the foregoing order, each class thereof being discharged in full when que, without regard to any subsequent class; but when the assets are insufficient to pay any class in full, after paying preceding classes, the claims due in such class shall be paid pro rata, according to the amounts thereof.

(7.) To distributeall remaining assets among the shareholders, 
after first equalizing the burdens to be borne by each, pro rata, in accordance with the terms and conditions upon which the stock was issued.

§ 193. Report of Receiver. Such receiver may at any time, by direction of the court, on its own motion, or upon application of an interested party, be required to make and file a report of his administration of the corporate affairs; any interested party may within thirty days after such report is filed, file objections thereto, and have a hearing thereon. When the administration is otherwise completed, but before distribution is made to shareholders, the receiver shall file in court a full report of his administration, and the proposed plan of distributing the remaining assets, if any, and ask the court to fix a time and place for hearing such report; the court shall make an order fixing the time and place thereof, and the receiver shall thereupon make publication of the fact of filing such report, and the time and place of hearing, at least once a wreek for four consecutive weeks in at least two newspapers of general circulation throughout the state in which the registered office is located; at such hearing objections may be filed thereto, and the court may make such ruling thereon as justice may require, including surcharging the account with any loss due to the failure of the receiver properly to administer the corporate affairs; and the proposed distribution may be approved, or modified, as the law and facts require, and payments ordered accordingly, and when made and reported to the court, such receiver shall be discharged.

UNIVHRSITY OF MTCHIGAXX

HORACE I. WIIGUS 